\title{
On the genus Candonopsis (Crustacea : Ostracoda : Candoninae) in Australia, with a key to the world recent species
}

\author{
I. Karanovic ${ }^{1}$ \\ P. Marmonier ${ }^{2}$
}

Keywords : Candonopsis, Candoninae, Ostracoda, taxonomy, Australia.

In the present paper Candonopsis murchisoni $\mathrm{n}$. sp., C. dani $\mathrm{n}$. sp., C. williami n. sp., C. kimberleyi n. sp., and C. westaustraliensis n. sp., are described, while $C$. tenuis (Brady, 1886) is redescribed. All species have been collected in the subterranean waters of Western Australia. The new species are easily distinguishable from the existing world species in details of the carapace, walking leg, cleaning leg, furca and hemipenis. Because of new features found, revised diagnosis and a key to the world species are provided. Some species, previously described in the genus Candonopsis Vavra, 1891, are considered as incertae sedis, while others are removed from this genus, which now contains 25 species. Finally, the authors propose the elevation of the subgenera Caribecandona Broodbakker, 1983 and Cubacandona Broodbakker, 1983 to the generic level.

Le genre Candonopsis (Crustacea : Ostracoda : Candoninae) en Australie, avec une clé des espèces actuelles mondiales

Mots-clés : Candonopsis, Candoninae, Ostracoda, taxonomie, Australie.

Dans cet article cinq espèces nouvelles australiennes du genre Candonopsis Vavra, 1891 - C. murchisoni n. sp., C. dani $n$. sp., C. williamia n. sp., C. kimberleyi $\mathrm{n}$. sp. et $C$. westaustraliensis n. sp. sont décrites et $C$. tenuis (Brady, 1886) est redécrite. Toutes ces espèces proviennent des eaux souterraines de l'Ouest de l'Australie. Ces nouvelles espèces se distinguent facilement des autres espèces connues dans le monde par des détails de leur carapace, de la patte marcheuse, de la patte nettoyeuse, de la furca et de l'hémipénis. Ces nouvelles descriptions permettent de réviser la diagnose du genre et d'établir une clé de détermination pour l'ensemble des espèces au niveau mondial. Certaines espèces attribuées à ce genre sont considérées comme incertae sedis, d'autres sont retirées du genre qui ne contient plus que 25 espèces. Enfin, les auteurs proposent d'élever les sous-genres Caribecandona Broodbakker, 1983 et Cubacandona Broodbakker, 1983 au niveau générique.

1. Western Australian Museum, Francis Street, Perth 6000, WA, Australia.

2. Université de Rennes 1, UMR-CNRS 6553, Station Biologique de Paimpont, F-35380 Paimpont, France. 


\section{Introduction}

The genus Candonopsis was established by Vavra (1891) with Candona kingsleii Brady \& Robertson, 1870 as the type species, described from south-east England (Brady and Robertson 1870). Daday (1900) marked Candonopsis kingsleii as a junior synonym of C. detecta (O. F. Müller, 1785). After rechecking Müller's (1785) drawings and description of Cypris detecta Müller, 1785 (see p. 49 and Tab. III, figs 1-3), it is obvious that Candonopsis kingsleii and $C$. detecta are not the same species, and that the former one even does not belong into the genus Candonopsis because it is clearly described and drawn that this species has posterior furcal seta. The main features of the genus, according to Vavra (1891), are : three branchial filaments on the exopodite of the first thoracic limb, elongated terminal segment of the mandibular palp, and lack of the posterior furcal seta. Similar diagnosis has been repeated several times later (Vavra 1895; Brady $1902 ; 1910)$. Danielopol (1980) revised the diagnosis and provided details of the cleaning leg, hemipenis, prehensile palps and Zenker's organ. He also gave a list of species then known, and commented on the zoogeography of the genus. However, some species were overlooked from the list and few were subsequently synonymized. Most of the species were discovered prior to 1960 's. Insufficient taxonomic descriptions caused systematic confusions as, for example found for Candonopsis scourfieldi Brady, 1910. Its poor description (Brady 1910) caused two synonyms (Petkovski \& Meisch 1995): Candonopsis parva Sywula, 1967 from Bulgaria, and C. stammeri Nuchterlein, 1969 from south-western Germany. Recent development in ostracod taxonomy, as well as new regions of investigation, led to the description of some new genera, which included species described previously in the genus Candonopsis. Such as Candonopsis cubensis Danielopol, 1978, described from subterranean waters of $\mathrm{Cu}-$ ba, and latter transfered by Broodbakker (1983) into the genus Caribecandona Broodbakker, 1983, described from Haiti. Today 26 recent species are considered to be valid, and these are, in alphabetical order: Candonopsis africana Klie, 1944; C. anisitsi Daday, 1905; C. anteroarcuata Rome, 1962; C. boui Danielopol, 1978; C. brasiliensis Sars 1901; C. bujukensis Löffler, 1968; C. calva Harding, 1962; C. columbiensis (Méhes, 1913); $C$. depressa Rome, 1962; C. dorsorecta Rome, 1962; C. falclandica Vavra, 1898; C. fessleri Löffler, 1968 (and subspecies C. $f$. daburui Löffler, 1968); C. hummelincki Broodbakker, 1983; C. kingsleii (Brady \& Robertson, 1870); C. mareza Karanovic \& Petkovski, 1999; C. nama Daday, 1913; C. navicula
Daday, 1910; C. putealis Klie, 1932; C. scourfieldi Brady, 1910; C. solitaria Vavra, 1895; C. sumatrana Klie, 1932; C. tenuis (Brady, 1886); C. thienemanni Schäfer, 1945 ; C. transgrediens Brehm, 1923; C. trichota Schäfer, 1945; and C. urmilae Gupta, 1988. However, among them, there are some obvious and some possible synonyms, and species with dubious descriptions and systematic positions, that will be discussed later. Sixteen fossil species are described in this genus, predominantly from Tertiary sediments (see Kempf $1980,1997)$. Some of these species have carapaces characteristics of the «fabaeformis» group of the genus Eucandona Daday, 1900, while others are hardly distinguishable from the recent representatives. Consequently, we include none of the fossils in the key to the world species provided in this paper.

The most common recent species of the genus is $C$. kingsleii, which inhabits mainly surface waters throughout Palearctic region (Löffler \& Danielopol 1978). Five species are known from Europe. Candonopsis scourfieldi can be found in both surface and interstitial habitats, while four other species are known exclusively from subterranean waters : $C$. thienemanni and $C$. trichota from Greece (Schäfer 1945), C. boui from France (Danielopol 1978; 1980), and C. mareza from Montenegro (Yugoslavia) (Karanovic \& Petkovski 1999). Other species of the genus are restricted to the subtropical and tropical regions. African continent has the greatest number of Candonopsis species, all being surface water inhabitants. They are as follows: $C$. solitaria described from Zanzibar, now Tanzania (Vavra 1895), and later found in Cameroon (Klie 1936); $C$. navicula, described from Kenya (Daday 1910) and found in Guinea (Klie 1935); C. nama, known only from Namibia (Daday 1913); C. africana, from Lake Kivu (Klie 1944), Lake Tanganyika (Rome 1962) and Sudan (Martens 1984); C. bujukensis, C. fessleri fessleri, C. fessleri daburai, described from Kenya (Löffler 1968); and finally $C$. anteroarcuata, C. depressa and $C$. dorsorecta, species endemic to Lake Tanganyika (Rome 1962). In contrast to Africa, only several species have been recorded from Central and South America : C. falklandica, from Falkland Islands (Vavra 1898); C. brasiliensis, from Brasil (Sars 1901), C. anisitsi, from Paragay (Daday 1905; Klie 1930); C. columbiensis, from Columbia (Méhes 1913), and $C$. hummelincki, from Haiti (Broodbakker 1983). From the Asian continent (excluding the Indian subcontinent) only $C$. transgrediens is known from the surface waters of Canton, today Guangzhou, south-east China (Brehm 1923). Candonopsis sumatrana, C. putealis and C. calva are descibed from Sumatra, Java and So- 
lomon Island respectively (Klie 1932, Harding 1962). Candonopsis sumatrana and C. calva are known only from surface waters, while $C$. putealis is described from subterranean waters (Klie 1932), and later found in surface waters of south-west India (Victor \& Fernando 1979). Only exclusively Indian species, $C$. urmilae is described from subterranean waters of northwestern India (Gupta 1988). Information on the Candoninae fauna of the Australian continent is almost entirely lacking. Until recently (Karanovic \& Marmonier in press) the only species belonging to this subfamily was Candonopsis tenuis (Brady, 1886) from New South Wales (Brady 1886), and from where was redescribed ten years latter by Sars (1896). This species has been reported from Sumatra (Klie 1932), and from Samoa and Tonga (Victor \& Fernando 1978), but a report of its distribution in South America (Müller 1912) is without proof, and may be erroneous.

During last several years intensive sampling of the subterranean waters of Western Australia has been undertaken by Dr William F. Humphreys from the Western Australian Museum. After examination of the material collected in Perth Basin, Murchison Region and Kimberley, totally six species of the genus Candonopsis are recorded : Candonopsis tenuis (Brady, 1886), C. murchisoni n. sp., $C$. dani n. sp., $C$. williami n. sp., $C$. kimberleyi $\mathrm{n}$. sp. and $C$. westaustraliensis $\mathrm{n}$. sp. C. tenuis is redescribed in this paper and a revised generic diagnosis is proposed. Also, a key to the world recent species of Candonopsis is presented.

\section{Methods}

Samples were collected with haul-nets (mesh size 250 or 350 micrometers) from groundwater monitoring bores, mineral exploration bores, water pumping bores and hand-dug pastoral wells, the latter usually rectangular-(ca. $1 \times 2 \mathrm{~m}$ ) or circular (ca $1.8 \mathrm{~m}$ diameter) and equipped with windmills, provide water for pastoral use. Many of these features are derelict. Bores are variously lined with steel or PVC pipes (the casing), usually $10-20 \mathrm{~cm}$ in diameter, that may have holes through it at particular depths (the slotting), or be open only at the bottom (piezometers). Mineral exploration bores (the Wagon Pass sites), are unlined. The top may be securely capped or entirely open to the elements. Except for the site at Eneabba and Wagon Pass, all wells and bores were located in groundwater calcrete deposits in the palaeodrainage system of the Western Shield region of Western Australia (Humphreys 1999, 2001). The Eneabba site is located in Tamala Limestone, a syngenetic karst of Pleistocene age. The Wagon Pass sites, Kimberley, are located in a rai- sed fossil reef karst of Devonian age that lies in the monsoonal tropical region of Western Australia.

Haul-nets are actually simple plankton nets of different sizes suitable for the bore, which can range from 30 to $180 \mathrm{~mm}$ in diameter. Weighed nets were lowered down into the bore with one bottle screwed on its distal part than hauled through the water column, usually a number of times. All samples were sorted while alive under stereo-microscope and the ostracods were then fixed in $70 \%$ or $100 \%$ ethyl-alcohol and assigned a field number (prefix BES).

A hand-net was used for sampling from some pastoral wells, and open pools. In some cases baited traps were used.

Ostracods were dissected in an equall mixture of distilled water and glycerol with fine entomological needles (mark 000). Dissected appendages and valves of some specimens were mounted in Faure's medium. The appendages of some specimens were mounted on slides in glycerol, while their valves are kept on micropalaeontological slides or in glass test-tubes in $70 \%$ alcohol. All non-dissected material is preserved in $70 \%$ ethyl-alcohol in glass test-tubes. Drawings have been prepared using a drawing tube attachment on Leica-DMLS microscope, with C-PLAN achromatic objectives. All the material is deposited in the Western Australian Museum.

In the systematic part of this paper the length of all segments was measured in the middle of the segments, and length ratios are presented beginning with the proximal end. The names of all appendages are used according to Martens (1998). The chaetotaxy of all limbs follows the model proposed by Broodbakker \& Danielopol (1982), revised for the antenna by Martens (1987), and for third thoracic leg by Meisch (1996). Lobes on hemipenis are marked according to Danielopol (1969).

Abbreviations used in text and figure legends: A1 antennula; A2 - antenna; BES - prefix for the field number; Fu - furca; GSWA - Geological Survey Western Australia; GWMB - Groundwater monitoring bore; H - height; L - length; LV - left valve; Md - mandible; Mxl - maxillula; RV - right valve; T1, T2, T3 first, second and third leg; W -width; WAM - Western Australian Museum.

Many bores, which put in for hydrogeological work, mineral exploration or water monitoring have prefixes or suffixes of relevance only to that drilling program. These codes are cited in the examined material for each species to aid specification of the location. 


\section{Results}

Family: Candonidae Kaufmann, 1900

Subfamily: Candoninae Kaufmann, 1900

\section{Genus: Candonopsis Vavra, 1891}

Revised diagnosis : Carapace reniform, triangular or trapezoidal. Valve surface smooth or ornamented. Marginal zone anteriorly not more than $20 \%$ of total length. Antennula 7 -segmented. Exopodite of antenna plate with two short and one long seta. Mandibular palp with one distal claw fused with segment. $\mathrm{L}: \mathrm{W}$ ratio of its terminal segment never less than $3: 1$. Terminal segment of maxillular palp strongly trapezoidal, penultimate segment very dilated, especially on it's distal end. Male's prehensile palps strongly asymmetrical : right one being more robust. T2 with or without seta on basal segment. Same appendage 5-segmented. T3 4 or 5-segmented with two, or three setae on basal segment. Terminal segment with one short and two long setae. Furca without posterior seta, posterior claw sometimes reduced. Hemipenis with characteristic appearance of «a» lobe: more or less triangular, but always distinctly higher than other two lobes. Zenker's organ with $5+2$ rows of spines, genital segment without extensions.

Type species: Candonopsis kingsleii (Brady and Robertson, 1870)

\subsection{Candonopsis tenuis (Brady, 1886)}

\section{(Figs 1-16)}

Material examined : 2 males, 1 female (WAM C28269 C28271, on slides), Well on Coolimba to Cliff head road, Eneabba, Perth Basin, Western Australia, Australia, $29^{\circ} 31^{\prime} \mathrm{S}, 114^{\circ} 59^{\prime} \mathrm{E}, 5$ June 1998 , leg. S. M. Eberhard (BES 5967.1).

Synonymy :

Candona tenuis n. sp. - Brady (1886) : p. 92, Plate 10, Figs 9,10 .

Candonopsis tenuis Brady - Sars (1896) : p. 62, Plate 7, Figs 6 (a-d).

Candonopsis tenuis (Brady) - Klie (1932) : p. 453; Victor \& Fernando (1978): p. 420

Candonopsis tenuis (Sars) - Danielopol (1980) : p. 319.

Redescription of male : Carapace in lateral view subreniform (Fig. 1). Dorsal margin broadly rounded towards caudal end and inclined towards frontal end. $\mathrm{L}$ of carapace $1.04 \mathrm{~mm}$. Greatest $\mathrm{H}$ lies on last third of $\mathrm{L}$, equalling $50.3 \%$ of $\mathrm{L}$. Caudal margin wider than frontal one. Both margins rounded. Posterior margin also slightly inclined in postero-ventral part. Ventral margin concave around middle. In dorsal view carapace with parallel lateral margins. Both anterior and posterior ends equally rounded. Greatest $\mathrm{W}$ around middle, equalling $33.3 \%$ of L. Marginal zone wider anteriorly $(15 \%$ of $L)$ than posteriorly $(9 \%$ of $L)$; line of concrescence narrow, with short and dense marginal pore canals. Selvage peripheral, and visible on both valves. Valve surface smooth and covered with short hairs.

A1 (Fig. 6) 7-segmented. First segment with one pappose seta antero-proximally (not shown on Fig. 6), one pappose seta antero-distally, reaching $1 / 3$ of third segment; two long setae posteriorly. Second segment with one pappose seta antero-distally, which reaches distal end of fifth segment. Following segment with one short seta (hardly reaching middle of fourth segment) postero-distally. Fourth segment with two long setae anteriorly (exceeding distal end of terminal segment), and one short seta posteriorly (not reaching distal end of sixth segment). Penultimate segment with total five setae, one of which being alpha (short, anterior one). Terminal segment with two long and one short seta, and aesthetasc (ya) which 1.2 times as long as terminal segment. $\mathrm{L}$ ratios of five distal segments $1.3: 1: 1.2: 1.2: 1.1$.

A2 (Fig. 5) with well developed male's sexual bristles. Exopodite with two short and one long seta. Aesthetasc Y 0.52 as long as first endopodal segment, y1 just slightly exceeding second endopodal segment, y2 not reaching distal end of terminal segment (not shown on Fig. 5), y3 as long as terminal segment. $\mathrm{L}$ ratio of four endopodal segments $3.7: 1.9: 1.3: 1$. Claw $\mathrm{G} 2$ and transformed seta $\mathrm{z} 2$ being of subequal $\mathrm{L}$ and 1.34 times as long as first endopodal segment. Claws $\mathrm{G} 1$ and $\mathrm{G} 3$ reduced, G1 still claw-like but just 1.8 times as long as terminal segment, while G3 seta-like and 1.3 times as long as terminal segment. Seta $z 1$ claw-like and 1.4 times as long as terminal segment, while $\mathrm{z} 3$ as long as same segment and seta-like. Claw GM well developed, and 1.1 times as long as first endopodal segment, $\mathrm{Gm} 1.3$ times as long as terminal segment.

Md (Fig. 7) with elongated terminal segment which 6.2 times as long as width. First segment of Md palp with one long and one short «S» seta, another pappose long seta, and one smooth alpha seta. Second segment with $3+2$ setae in bunch (all setae pappose), and two setae externally. Penultimate segment with two pappose setae extero-medially, to extero-distally, one seta extero-distally, and three intero-distally. Terminal segment with fused, distally pappose claw, one seta externally and two setae internally. Subterminal and terminal segments of subequal $\mathrm{L}$.

Mxl palp (Fig. 9) with four pappose setae distally on first segment, and six appendages (two more claw like, three seta like) on terminal segment. 


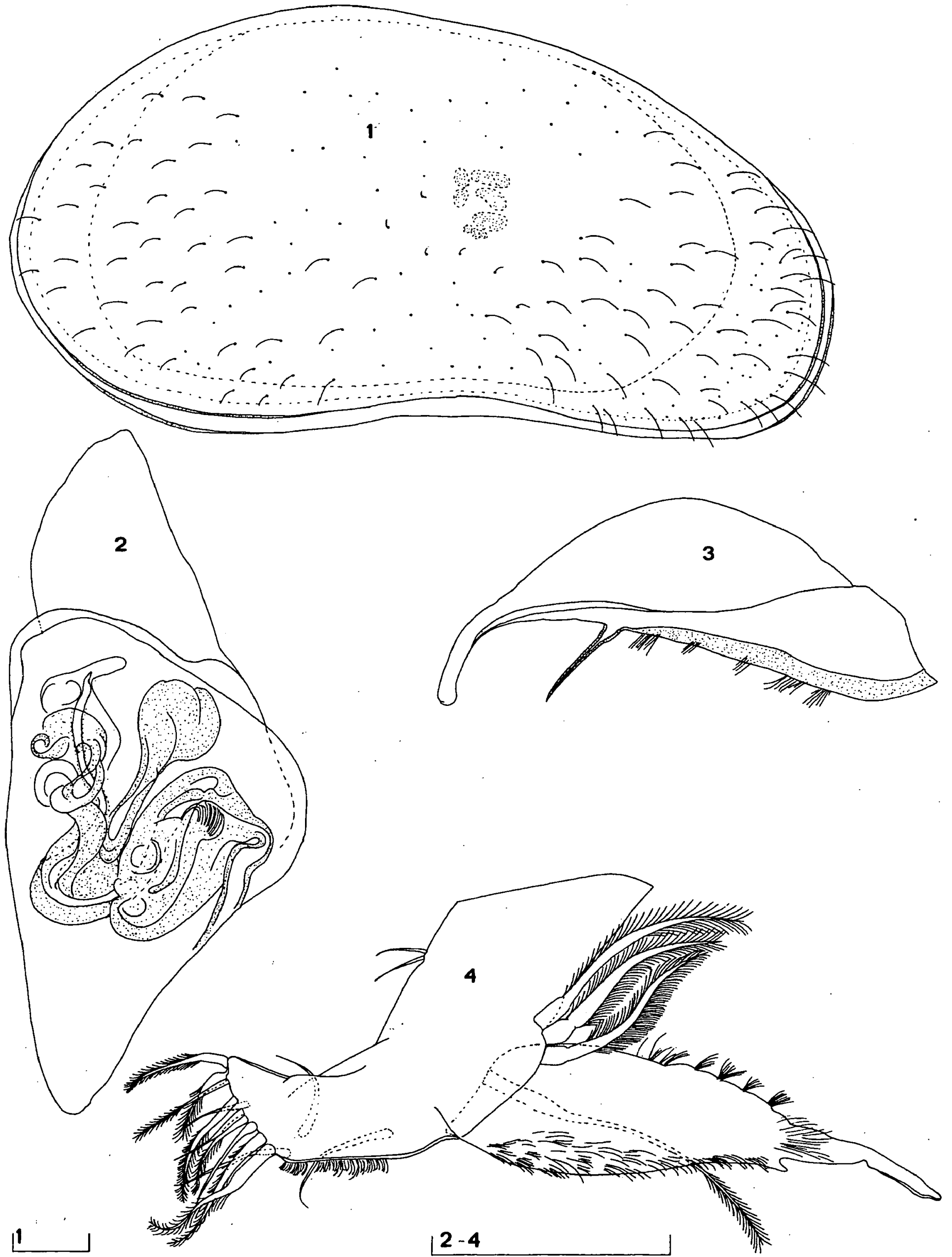

Figs 1-4. Candonopsis tenuis (Brady, 1886); WAM C28269 (male, L=1.04 mm): 1-carapace, lateral view; 2-hemipenis; 3-right prehensile palp; 4-T1 with left prehensile palp. Scales $=0.1 \mathrm{~mm}$.

Figs 1-4. Candonopsis tenuis (Brady, 1886); WAM C28269 (m,le, L=1.04 mm): 1-carapace, vue latérale; 2-hémipénis; 3-palpe préhensile droit; 4-T1 avec palpe préhensile gauche. Echelle $=0.1 \mathrm{~mm}$. 


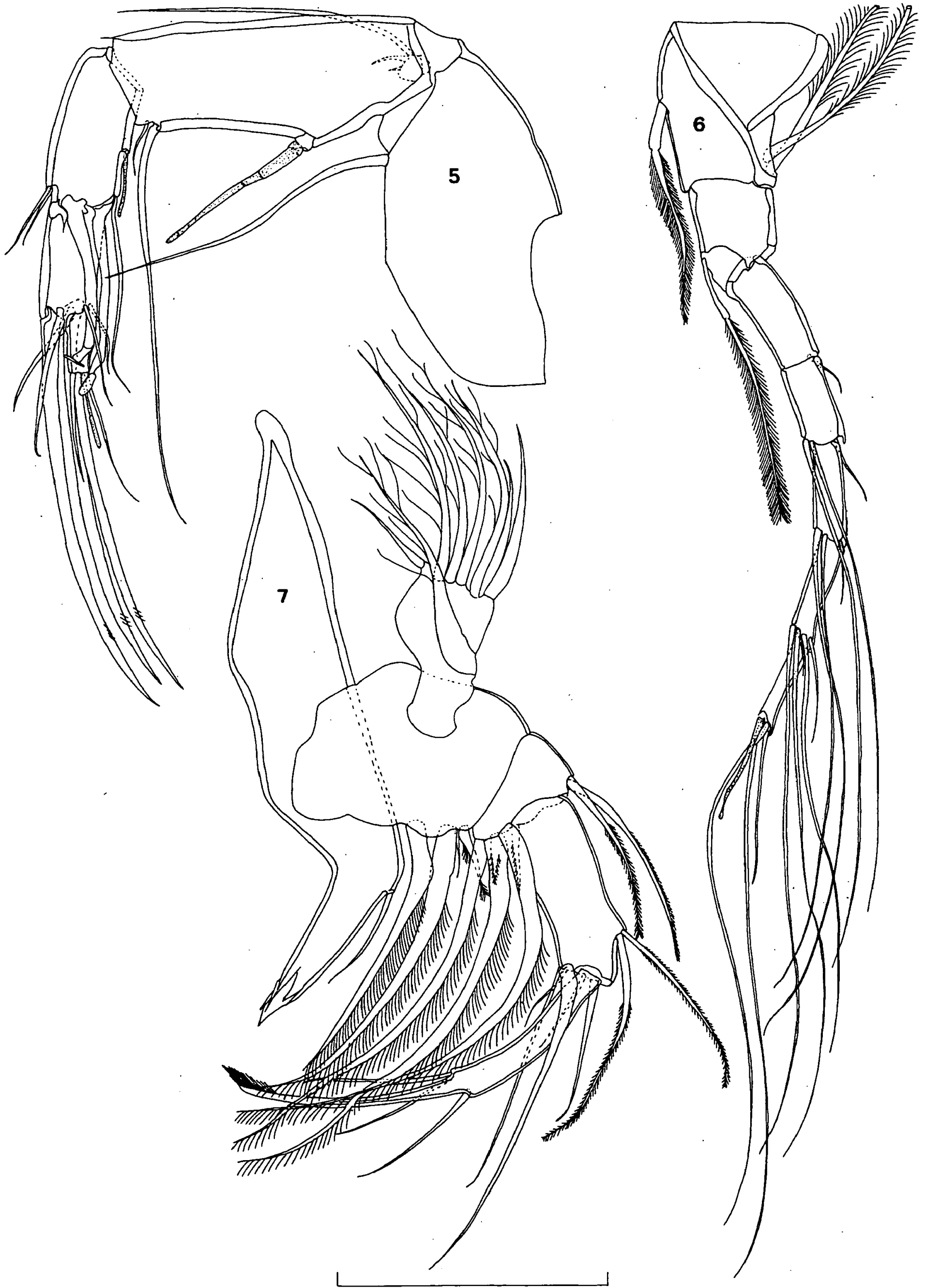

Figs 5-7. Candonopsis tenuis (Brady, 1886); WAM C28269 (male, $\mathrm{L}=1.04 \mathrm{~mm}$ ): 5-A2; 6-A1; 7-Md. Scale $=0.1 \mathrm{~mm}$. Figs 5-7. Candonopsis tenuis (Brady, 1886); WAM C28269 (mâle, L = $1.04 \mathrm{~mm}$ ): 5-A2; 6-A1; 7-Md. Echelle $=0.1 \mathrm{~mm}$. 
(7)

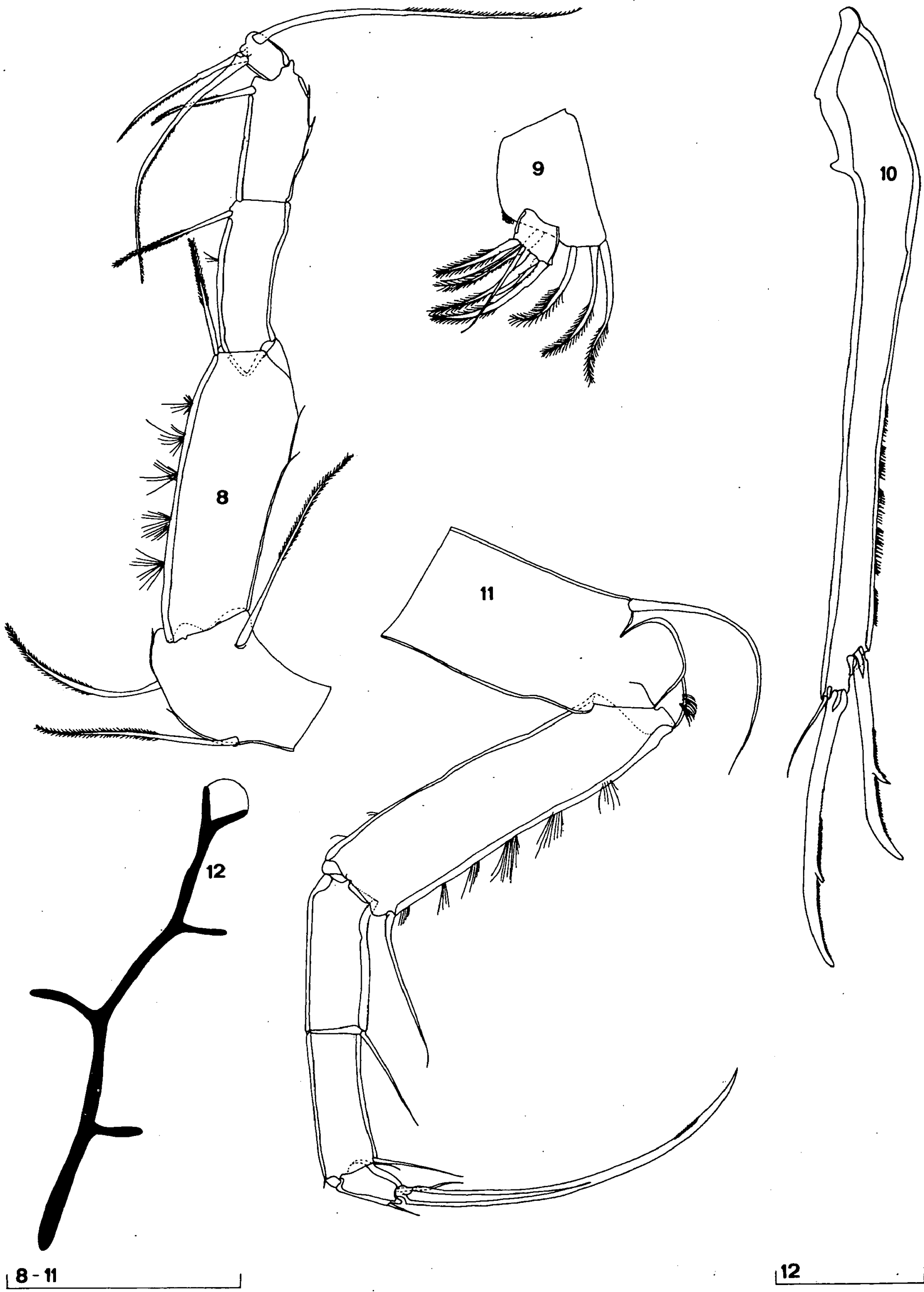

Figs 8-12. Candonopsis tenuis (Brady, 1886); WAM C28269 (male, L=1.04 mm); 8-T3; 9-Mxl palp; 10-Fu; 11-T2; 12-furcal attachment. Scales $=0.1 \mathrm{~mm}$.

Figs 8-12. Candonopsis tenuis (Brady, 1886); WAM C28269 (mâle, L = 1.04 mm); 8-T3; 9-Mxl palp; 10-Fu; 11-T2; 12-attache de la furca. Echelle $=0.1 \mathrm{~mm}$. 

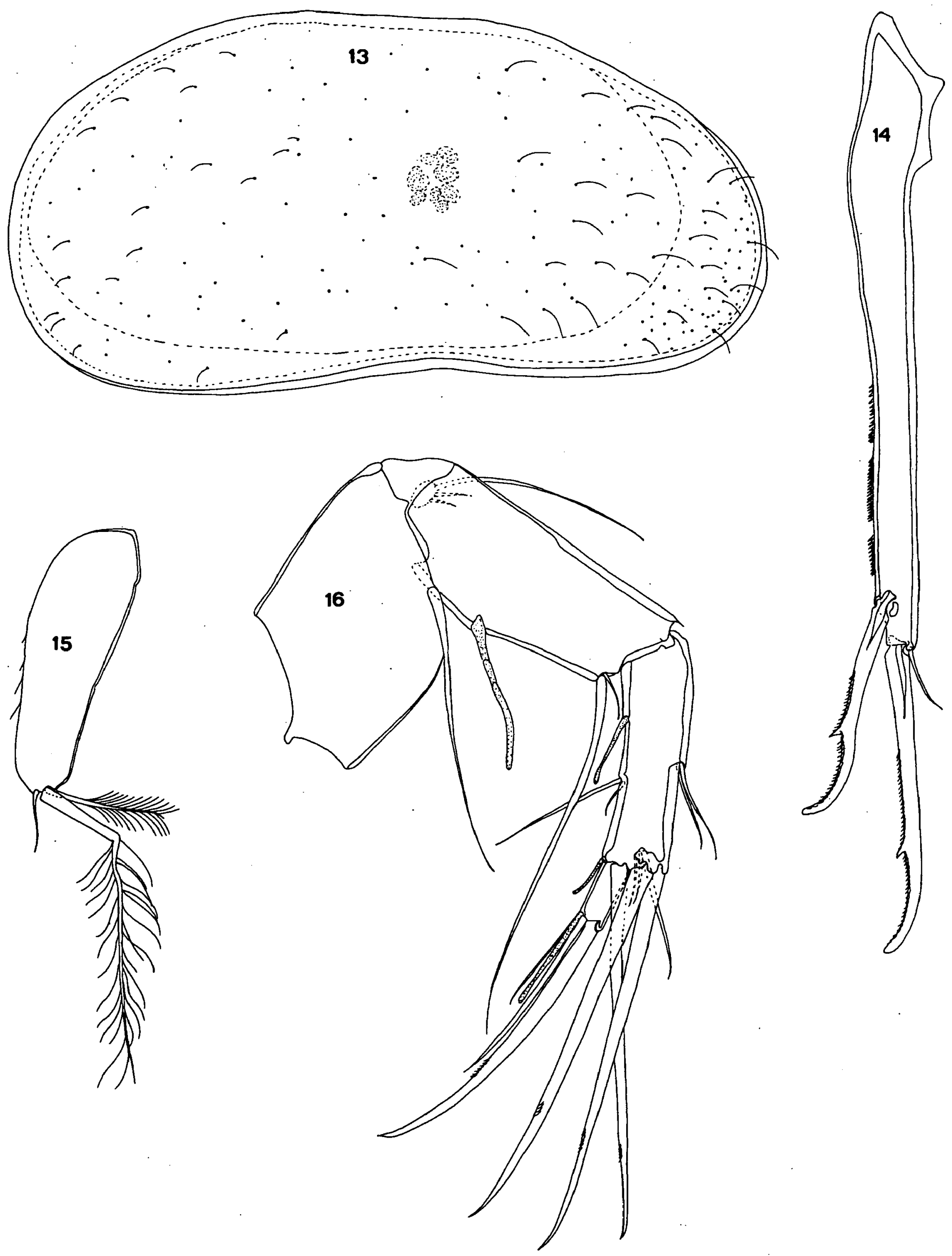

Figs 13-16. Candonopsis tenuis (Brady, 1886); WAM C28271 (female, L = $0.922 \mathrm{~mm}$ ): 13-carapace, lateral view; 14-Fu; 15-endopodite T1 (detail); 16-A2. Scales $=0.1 \mathrm{~mm}$.

Figs 13-16. Candonopsis tenuis (Brady, 1886); WAM C28271 (femelle, L = $0.922 \mathrm{~mm}$ ): 13-carapace, vue latérale; 14-Fu; 15-endopodite T2 (détail); 16-A2. Echelle $=0.1 \mathrm{~mm}$. 
Enopodites T1 transformed into male's prehensile palps, of which right one (Fig. 3) being stronger, with long sclerified subapical structure and finger, while left one (Fig. 4) with very short subapical structure. T1 with two «a» setae, «b» and «d» setae developed. Exopodite with three branchial filaments.

T2 (Fig. 11) 5-segmented. Basal segment with one long seta, first endopodal segment with one seta which exceeds distal end of following segment. Second segment with one seta (reaching distal end of penultimate segment). Penultimate segment with one very short, tiny seta, other one being three times longer. Terminal segment carries two short setae, and claw, which 1.05 times as long as three distal segments combined, and being distally serrated.

T3 (Fig. 8) 4-segmented. Basal segment with three pappose setae (d1, d2, dp). First edopodal segment with few bunches of hairs on internal margin, and with «e» pappose seta (not reaching distal end of following segment). Third and fourth segments with one pappose seta each ( «f» and «g»), being of almost subequal $L$ (about as long as penultimate segment). Terminal segment carries setae $h 1, h 2$ and h3 with $L$ ratio $1: 1.7$ : 2.2 .

Furca (Fig. 10) with both claws well developed, each with one strong spine. Posterior margin with row of short spines. $L$ ratios of anterior margin, anteror and posterior claws $2.5: 1.25: 1$. Anterior claw three times longer than anterior seta. Furcal attachment shown on Fig. 12.

Hemipenis (Fig. 2) with all three lobes well developed, lobe «a» being triangular and distally pointed, both lobes «b» and «h» rounded, «h» more evenly than «b».

Redescription of female: Carapace less reniform than in male (Fig. 13), and dorsal margin with one «flat» part around middle. Same margin than inclined towards frontal margin, and widely rounded towards caudal one. Caudal margin not inclined postero-ventrally. $\mathrm{L}=0.922 \mathrm{~mm}$; greatest $\mathrm{H}=50 \%$ of $\mathrm{L}$, greatest $\mathrm{W}=37 \%$ of $\mathrm{L}$.

A2 (Fig. 16) 4-segmented. $L$ ratio of three endopodal segments $3.8: 3: 1$. Aesthetasc $\mathrm{Y} 0.6$ times as long as first endopodal segment, $y 1$ reaching middle of second endopodal segment, y2 almost reaching distal end of terminal segment, y3 1.5 times as long as terminal segment. Just two «t» setae present. All claws on penultimate segment well developed and about 1.5 times as long as first endopodal segment. Seta $\mathrm{z} 1$ transformed into claw which 1.8 times as long as terminal segment, while other two «Z» setae short and 0.7 times as long as same segment. Claw GM 1.2 times as long as first, while $\mathrm{Gm} 0.7$ times as long as terminal segment.

Endopodite T1 (Fig. 15) with two pappose and one smooth seta terminally, with $L$ ratios $1: 2: 5$.

Both furcal claws (Fig. 14) with well developed spines. $L$ ratios of anterior margin, anterior, and posterior claws being $2.1: 1.34: 1$. Genital segment well rounded and without extensions .

All other appendages (A1, Md, Mxl, T2, T3) same as in male.

\subsection{Candonopsis murchisoni n. sp.}

(Figs 17-37)

Material examined : 1. Holotype, male (WAM C28272), allotype, female (WAM C28273), and paratype, female (WAM C28274, in alcohol), from Old Cue water supply bores, Murchison Region, Western Australia, Australia, $27^{\circ} 16^{\prime} \mathrm{S}, 117^{\circ} 54^{\prime} \mathrm{E}, 13$ May 1999 , leg. W. F. Humphreys and H. J. Hahn (BES 7226); 2. female (WAM C28275, in alcohol), Old Cue water supply bores, Murchison Region, Western Australia, Australia, 27 ${ }^{\circ} 16^{\prime}$ 'S, $117^{0} 59^{\prime} \mathrm{E}, 12$ May 1999, leg. W. F. Humphreys \& H. J. Hahn (BES 7041); 3. One male, 4 females and 2 juveniles (WAM C28276-28277, on slides, C28278 in alcohol), Old Cue water supply bores, Murchison Region, Western Australia, Australia, $27^{\circ} 16^{\prime}$ 'S, $117^{\circ} 59^{\prime} \mathrm{E}, 12$ May 1999 , leg. W. F. Humphreys \& H. J. Hahn (BES 7044); 4. One female, 2 juveniles (WAM C28279 in alcohol), Old Cue water supply bores, Murchison Region, Western Australia, Australia, $27^{\circ} 16^{\prime} \mathrm{S}, 117^{\circ} 59^{\prime} \mathrm{E}, 12$ May 1999, leg. W. F. Humphreys \& H. J. Hahn (BES 7046); 5. Three males, 12 females (WAM C28280 in alcohol), Nannie Station, Old Cue water supply bore, Murchison Region, Western Australia, Australia, 27 $16^{\prime} 11^{\prime \prime} \mathrm{S}, 170^{\circ} 59^{\prime} 23^{\prime \prime} \mathrm{E}, 05$ May 2001, leg. W. F. Humphreys, C. H. S. Watts \& S. J. B. Cooper (BES 5570).

Etymology : The specific name is derived from «Murchison», the region where it was collected.

Description of male (Holotype): In lateral view carapace subreniform (Figs 17, 18). When seeing from left side RV clearly overlapping LV with flange. On LV (Fig. 17) dorsal margin flatter in middle than on RV (Fig. 18) where dorsal margin more evenly rounded. Dorsal margin slopping almost equally towards both caudal and frontal margins. Both those margins broadly rounded, and frontal being just slightly broader than caudal one. Ventral margin slightly concave on $\mathrm{LV}$, and more concave on RV. L of carapace $0.871 \mathrm{~mm}$. Greatest $\mathbf{H}$ lies well behind middle, equalling $53 \%$ of $\mathrm{H}$. In dorsal view (Fig. 22) LV overlapping RV well both on anterior and posterior ends. Anterior end being slightly narrower than posterior one. Greatest W lies around 

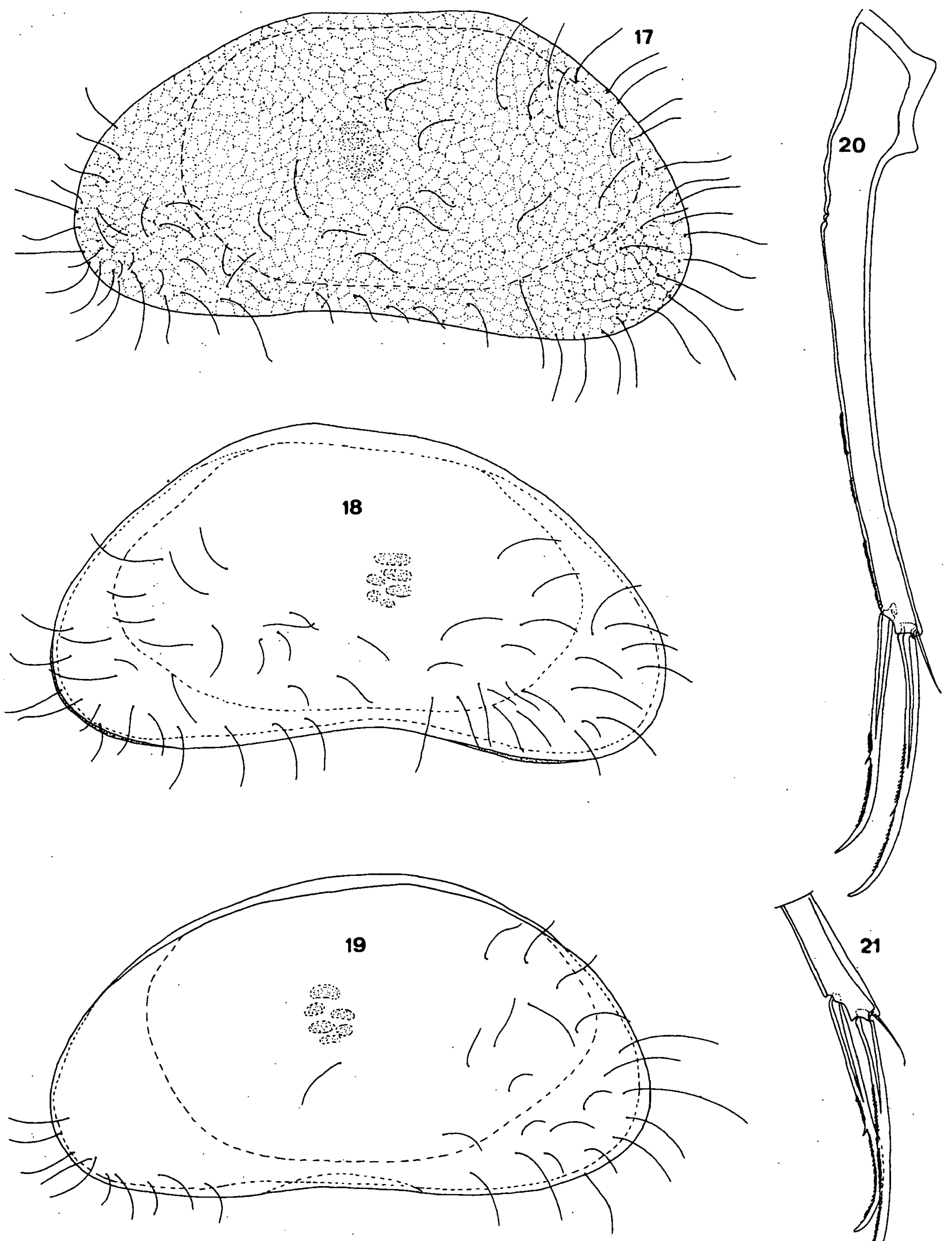

\section{1}

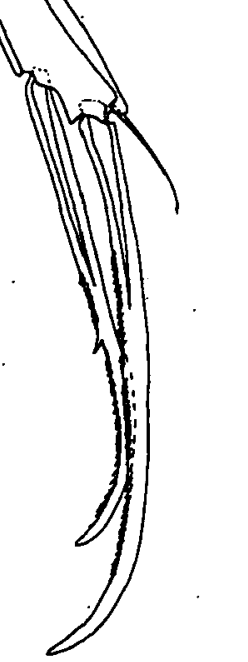

17- 19

20,21

Figs 17-21. Candonopsis murchisoni n. sp.; 17, 18, 20, 21 holotype (male, L = 0.871 mm); 19, WAM C28276 (male, L=0.842 mm): $17-\mathrm{LV}$, external view; 18-RV, external view; 19-carapace, lateral view; 20-Fu; 21-Fu, detail. Scales $=0.1 \mathrm{~mm}$.

Figs 17-21. Candonopsis murchisoni n. sp.; 17, 18, 20, 21 holotype (mâle, L=0.871 mm); 19, WAM C28276 (mâle, L=0.842 mm): $17-\mathrm{LV}$, vue externe; 18-RV, vue externe; 19-carapace, vue latérale; 20-Fu; 21-Fu, détail. Echelle $=0.1 \mathrm{~mm}$. 
(11)
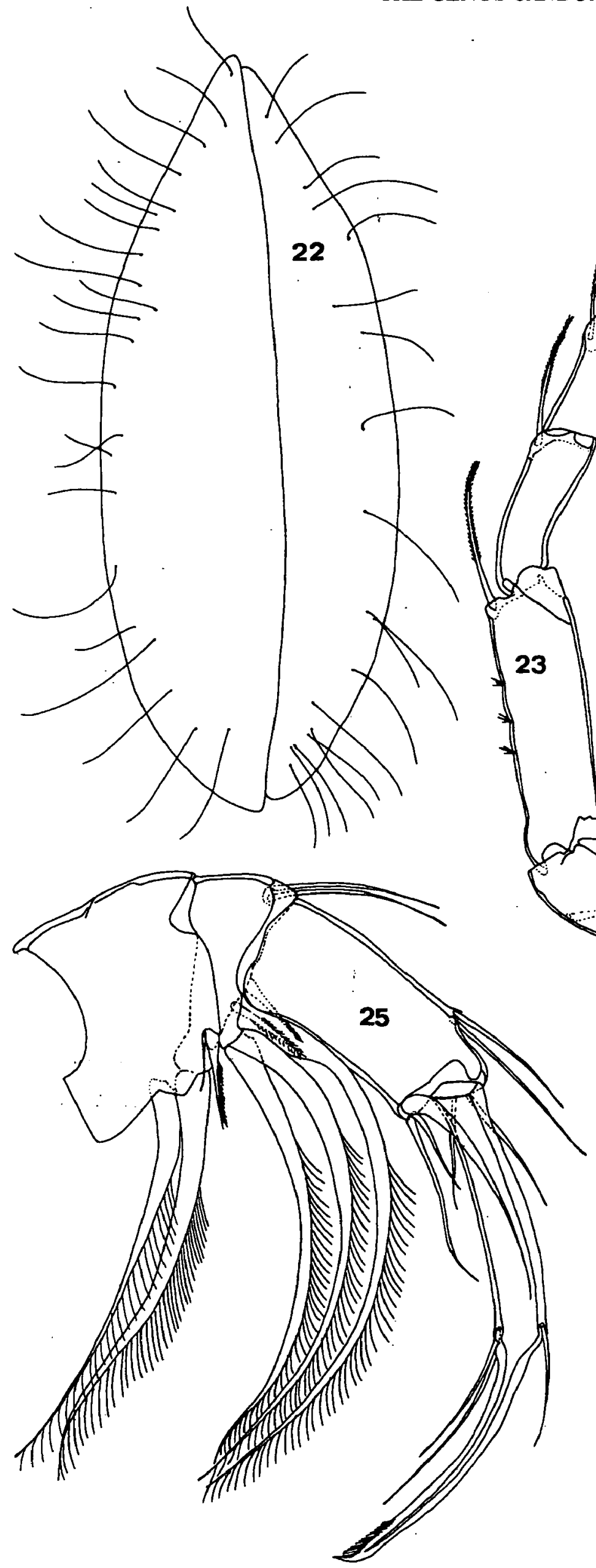

122

23

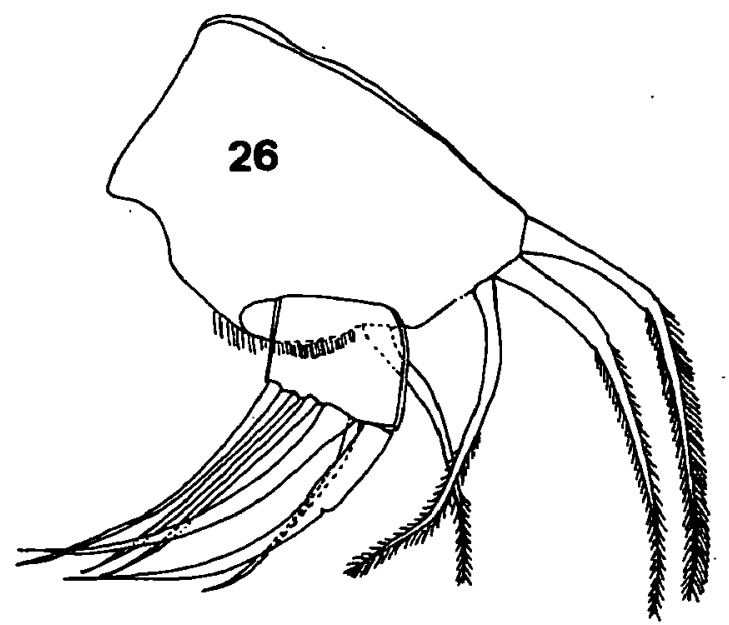

26

Figs 22-26. Candonopsis murchisoni sp. nov; holotype (male, L = $0.871 \mathrm{~mm}$ ): 22-carapace, dorsal view; 23-T3; 24-hemipenis; 25-Md palp; 26-Mxl palp. Scales $=0.1 \mathrm{~mm}$.

Figs 22-26. Candonopsis murchisoni sp. nov; holotype (mâle, L = 0.871 mm): 22-carapace, vue dorsale; 23-T3; 24-hémipénis; 25-palpe Md; 26-palpe Mxl. Echelle $=0.1 \mathrm{~mm}$. 


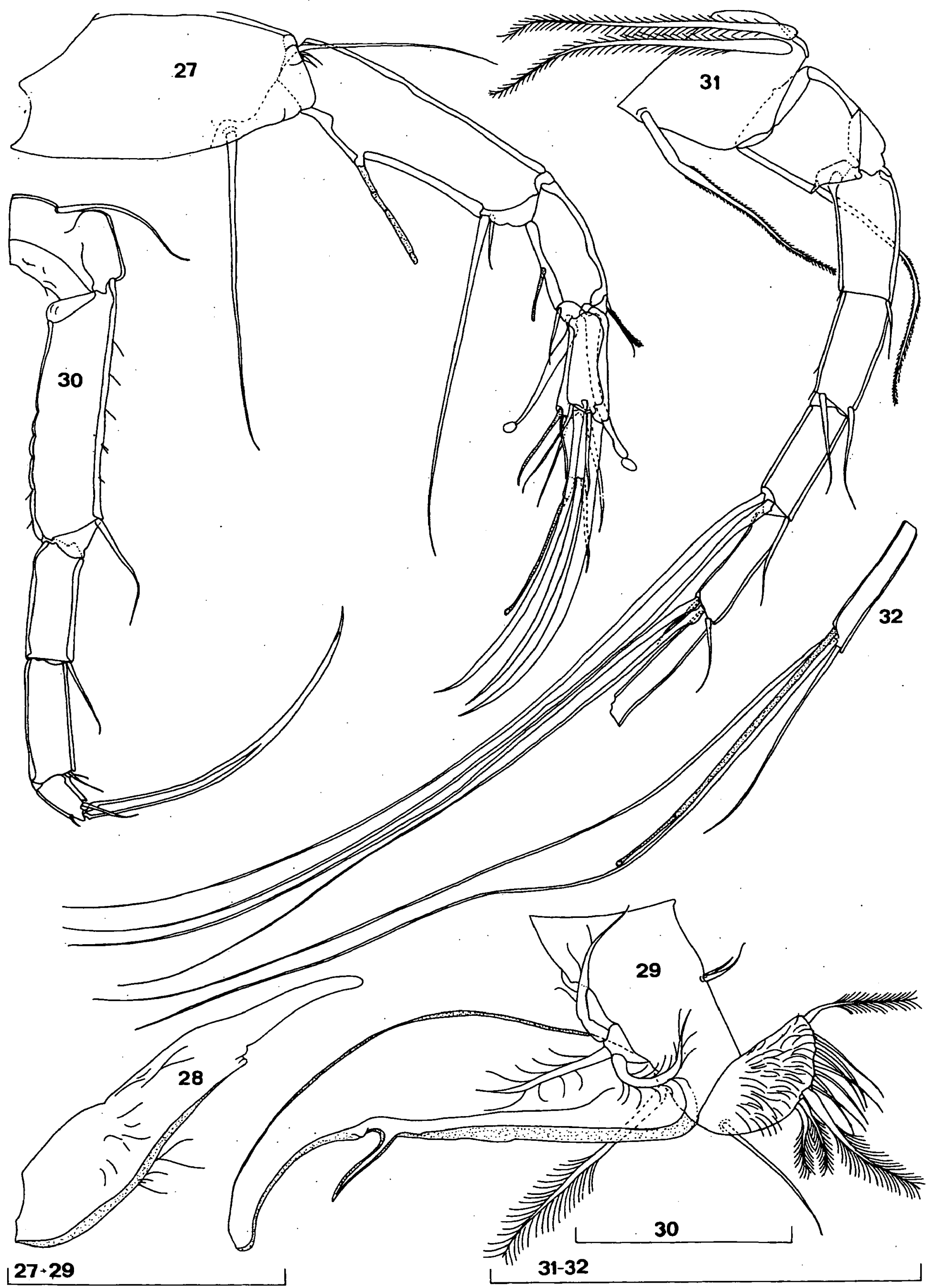



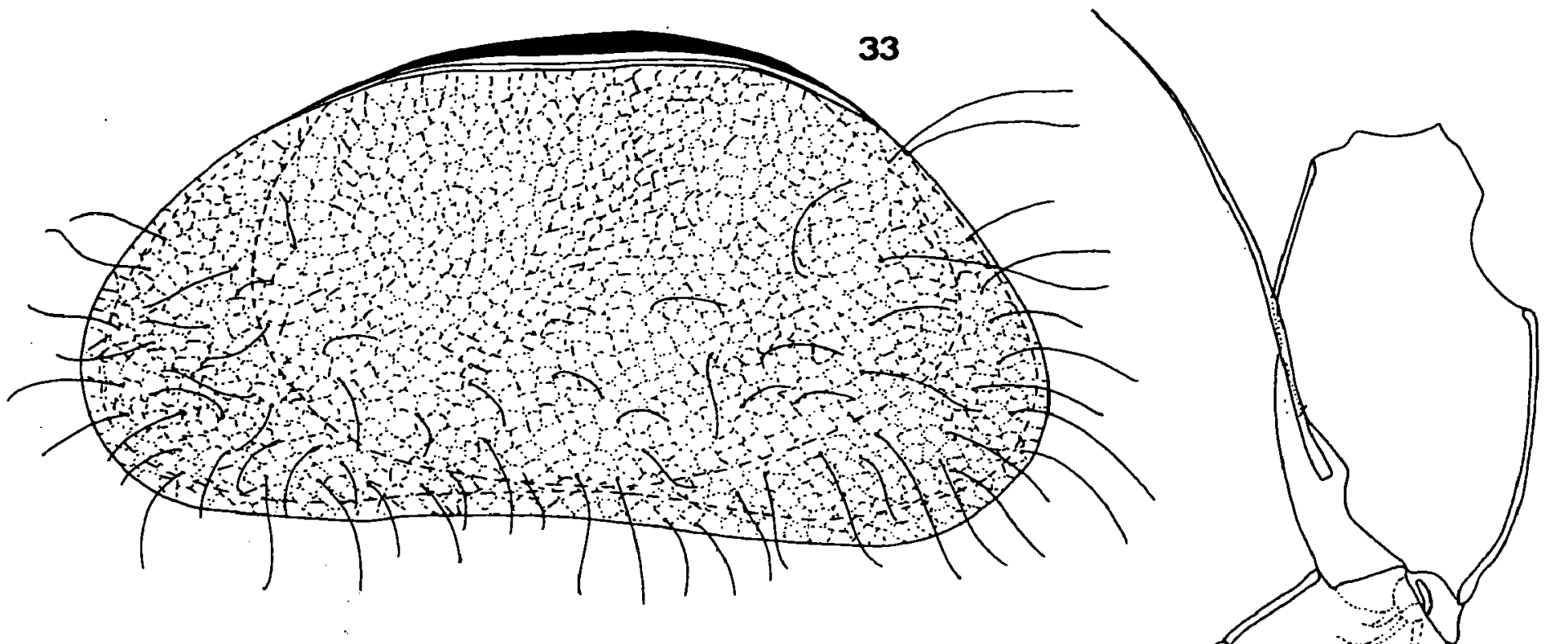

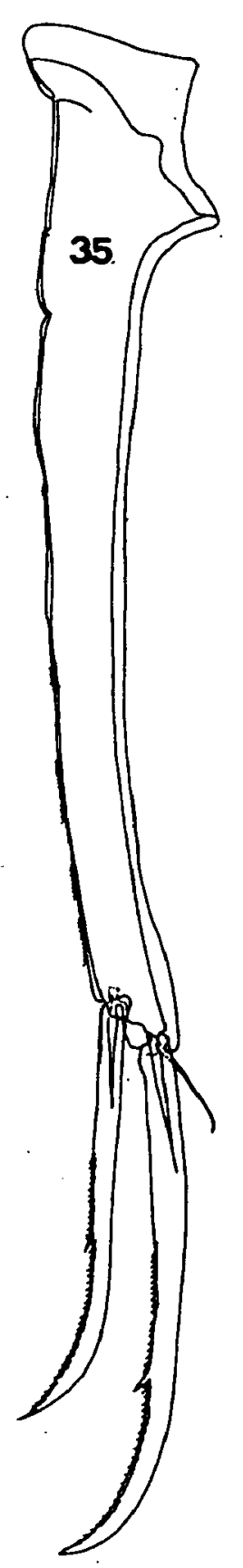

33,34
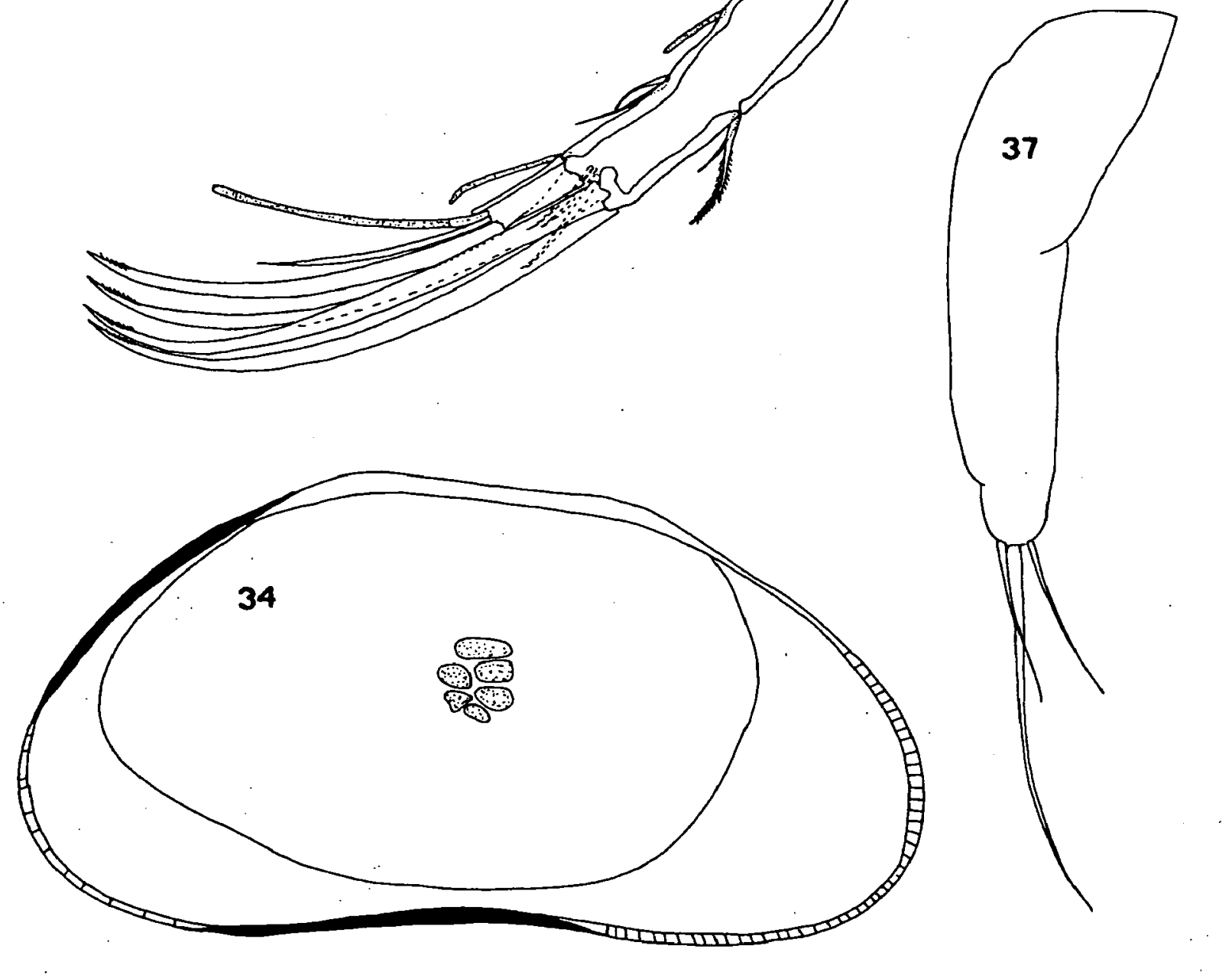

137

Figs 33-37. Candonopsis murchisoni $\mathrm{n}$. sp.; allotype (female, $\mathrm{L}=0.825 \mathrm{~mm}$ ): 33-carapace, lateral view; 34-LV, internal view; 35-Fu; 36-A2; 37endopodite T1 (detail). Scales $=0.1 \mathrm{~mm}$.

Figs 33-37. Candonopsis murchisoni $\mathrm{n}$. sp.; allotype (femelle, $\mathrm{L}=0.825 \mathrm{~mm}$ ): 33-carapace, vue latérale; 34-LV, vue interne; 35-Fu; 36-A2; 37endopodite T1 (détail). Echelle $=0.1 \mathrm{~mm}$. 
middle, equalling $37.8 \%$ of $\mathrm{L}$. Marginal zone broader anteriorly ( $19 \%$ of $\mathrm{L})$, than posteriorly ( $15 \%$ of $\mathrm{L})$. Line of concrescence narrow, consisting of short dense pore canals. Selvage peripheral and visible just on RV. Surface covered with hairs, that longer on caudal end. Also, surface very finely ornamented with rete-like patterns, hardly visible.

A1 (Fig. 31) 7-segmented. First segment with one long, pappose seta antero-distally, and antero-proximally (not shown on Fig. 31), and other two pappose setae postero-distally. Second segment with long pappose seta, which reaches distal margin of fourth segment. Third segment with one short seta (not reaching middle of following segment) postero-distally. Fourth segment with two setae distally, of subequal L (not reaching distal end of following segment). Fifth segment with one short seta postero-distally, and two long setae antero-distally. Penultimate segment with four setae visible (alpha seta, very short and hardly visible). Terminal segment (Fig. 32) with aesthetasc which 2.4 time as long as same segment. All segments about equally long ( $L$ ratios $1: 1: 1: 1.1: 1.2$ ).

A2 (Fig. 27) 5-segmented, and with male's bristles developed. Aeshetasc Y 0.42 times as long as first endopodal segment, $y 1$ reaching distal end of second endopodal segment, y2 exceeding distal end of terminal segment, y3 1.5 times as long as terminal segment. Exopodite consists of two short and one long seta. Claw G2, as well as transformed $\mathrm{z} 2$ seta about equally long and 1.2 times as long as first endopodal segment. Claw G1 and G3 reduced, G1 claw-like but only two times as long as terminal segment, latter one seta-like and 1.6 times as long as same segment. Seta $z 1$ as long, while z3 1.7 times as long as terminal segment. Terminal segment with GM which 0.9 times as long as first endopodal segment, while $\mathrm{Gm} 1.3$ times as long as terminal one. $L$ ratios of four endopodal segments 4.6 : $2.3: 1.8: 1$.

Md palp (Fig. 25) with $2+3$ setae in bunch on second segment, two setae externally on same segment, two setae extero-distally, and five setae distally on subterminal segment. $\mathrm{L}: \mathrm{W}$ ratio of terminal segment 5.25 : 1. Same segment with one fused, distally pappose claw, one seta externally, and two setae internally. Penultimate and terminal segments of subequal $L$.

Mxl palp with four pappose setae distally on first segment and six appendages (two claw-like) on terminal segment.

Prehensile palps (Figs 28,29$)$ strongly asymmetrical, right one with long sclerified subapical structure, left with very short and hardly visible one. Two «a» se- tae present, «b» and «d» setae also developed. Three branchial filaments on exopodite.

T2 (Fig. 30) 5-segmented. Basal segment with one long seta. First endopodal segment with one distal seta not reaching distal end of following segment. Second endopodal segment with one seta reaching last third of penultimate segment. Fourth segment with two setae (both short), while terminal segment carries two setae and claw, which 1.1 times as long as three distal segments combined, and distally slightly serrated.

T3 (Fig. 23) 5-segmented. Basal segment with d1, d2 and dp setae. First endopodal segment with pappose «e» seta (not reaching distal end of following segment). Setae «f» and «g» pappose, subequally long (as long as second endopodal segment). L ratios of $h 1, h 2$ and h3 setae as follows $1: 1.8: 2$. All setae pappose.

Furca (Fig. 20) with rows of small tiny spines on posterior margin. Both claws developed and with one fine spine each. Claws also serrated. $L$ ratios of anterior margin, anterior and posterior claws $1.9: 1.1: 1$. Anterior seta being four times shorter than anterior claw.

Hemipenis (Fig. 24) with all lobes developed. Lobe «b» with one squarish protuberance, lobe «a» triangular and distally pointed, «h» lobe rounded.

Description of female (Allotype) : In lateral view (Fig. 33) same as in male: RV overlapping with flange LV. $\mathrm{L}=0.825 \mathrm{~mm}$. Greatest $\mathrm{H}$ lies behind middle and equals $53 \%$ of L. Ornamentation and other characteristics of carapace, same as in male.

A2 (Fig. 36), 4-segmented. Aesthetasc Y 0.43 times as long as first endopodal segment, y1 reaching middle of second endopodal segment, y2 exceeds distal end of terminal segment, while y 3 being 2.3 times as long as terminal segment. Just two «t» setae developed. All claws on penultimate segment well developed, 1.2 times L of first endopodal segment. Seta $\mathrm{z} 1$ more clawlike (as long as terminal segment), setae $\mathrm{z} 2$ and $\mathrm{z} 3$ small and 0.7 times as long as terminal segment. Claw GM 0.9 times as long as first endopodal segment, while $\mathrm{Gm} 2.3$ times as long as terminal segment. $\mathrm{L}$ ratios of three endopodal segments $4.5: 3.3: 1$.

Endopodite of T1 (Fig. 37) distally with two setae of same $\mathrm{L}$ and longer one.

Fu (Fig. 35) with $\mathrm{L}$ ratios of anterior margin, anterior and posterior claws $2: 1.2: 1$. Both furcal claws with small spines. Spine on anterior claw stronger than posterior one. Genital segment rounded, and without any extensions. 
All other appendages (A1, Md, Mxl, T2, T3) same as in male.

Variability : On one furcal ramus (Fig. 21) anterior claw was without spine. The $\mathrm{L}$ of males varied between $0.83 \mathrm{~mm}$ and $0.88 \mathrm{~mm}$. In females also slight variability in L of carapace was noticed: from $0.82 \mathrm{~mm}$ to $0.87 \mathrm{~mm}$.

\subsection{Candonopsis dani n. sp.} (Figs 38-59)

Material examined : 1. Holotype, male (WAM C28281), allotype, female (WAM C28282), and paratypes: 5 males, 31 females and 212 juveniles (WAM C28283 on slide, C28284 in alcohol), GWMB next to Pump 1, Lake Violet Borefield, Wiluna, Murchison Region, Western Australia, Australia, $26^{\circ} 40^{\prime} \mathrm{S}, 120^{\circ} 14^{\prime} \mathrm{E}, 18$ May 1999 , leg. W. F. Humphreys \& H. J. Hahn (BES 7145); 2. one juvenile (WAM C28285 in alcohol), GWMB next to Pump 1, Lake Violet Borefield, Wiluna, Murchison Region, Western Australia, Australia, $26^{\circ} 40^{\prime}$ 'S, $120014^{\prime}$ E, 18 May 1999 , leg. W. F. Humphreys \& H. J. Hahn (BES 7153); 3. Seven juveniles (WAM C28286 in alcohol), GWMB next to Pump 1, Lake Violet Borefield, Wiluna, Murchison Region, Western Australia, Australia, $26^{\circ} 40^{\prime} \mathrm{S}, 120^{\circ} 14^{\prime} \mathrm{E}, 18$ May 1999 , leg. W. F. Humphreys \& H. J. Hahn (BES 7243); 4. One juvenile (WAM C28287 in alcohol), GWMB next to Pump 1, Lake Violet Borefield, WiIuna, Murchison Region, Western Australia, Australia, $26^{\circ} 40^{\prime}$ 'S, $120^{\circ} 14^{\prime} \mathrm{E}, 18$ May 1999 , leg. W. F. Humphreys \& H. J. Hahn (BES 7235); 5. One female, 1 juvenile (WAM C28288 on slide, C28289 in alcohol), GWMB next to Pump 1, Lake Violet Borefield, Wiluna, Murchison Region, Western Australia, Australia, $26^{\circ} 40^{\prime} \mathrm{S}, 120^{\circ} 14^{\prime} \mathrm{E}, 18$ May 1999 , leg. W. F. Humphreys \& H. J. Hahn (BES 7147.1); 6. Six males, 1 female and 21 juvenile (WAM C28290, C28291 on slides, C28292 in alcohol), GWMB next to Pump 1, Lake Violet Borefield, Wiluna, Murchison Region, Western Australia, Australia, $26^{\circ} 40^{\prime} \mathrm{S}, 120^{\circ} 14^{\prime} \mathrm{E}, 18$ May 1999 , leg. W. F. Humphreys and H. J. Hahn (BES 7152); 7. Fifteen juveniles (WAM C28293 in alcohol), GWMB next to Pump 1, Lake Violet Borefield, Wiluna, Murchison Region, Western Australia, Australia, $26^{\circ} 40^{\prime}$ 'S, $120^{\circ} 14^{\prime} \mathrm{E}, 18$ May 1999 , leg. W. F. Humphreys and H. J. Hahn (BES 7233); 8. Two males, 1 females and 8 juveniles (WAM C28294 in alcohol), GWMB next to Pump 1, Lake Violet Borefield, Wiluna, Murchison Region, Western Australia, Australia, $26^{\circ} 40^{\prime} \mathrm{S}, 120^{\circ} 14^{\prime} \mathrm{E}, 18$ May 1999, leg. W. F. Humphreys \& H. J. Hahn (BES 7159); 9. Five juveniles (WAM C28295, in alcohol), XP5 GWMB, Lake Violet Borefield, Wiluna, Murchison Region, Western Australia, Australia, 26⒋ '08'S, $120^{\circ} 13^{\prime} 05^{\prime}$ 'E, 08 May 2001, leg. W. F.Humphreys, C. H. S. Watts \& S. J. B. Cooper (BES 7276); 10. Twenty one females, 13 males and 32 juveniles (WAM C28296 in alcohol), XP1 GWMB, Lake Violet Borefield, Wiluna, Murchison Region, Western Australia, Australia, 264ㅇ's, 120014'E, 08 My 2001, leg. W. F. Humphreys, C. H. S. Watts and S. J. B. Cooper (BES 7274); 11. Four juveniles (WAM C28297 in alcohol), XP5 GWMB, La- ke Violet Borefield, Wiluna, Murchison Region, Western Australia, Australia, $26^{\circ} 41^{\prime} 08^{\prime \prime} \mathrm{S}, 120^{\circ} 13^{\prime} 05^{\prime \prime} \mathrm{E}, 08$ May 2001, leg. W. F.Humphreys, C. H. S. Watts \& S. J. B. Cooper (BES 7259); 12. One male, 3 females and 5 juveniles (WAM C28298 in alcohol), mineral exploration bore near Bubble Well, Millbillillie Station, Wiluna, Murchison Region, Western Australia, Australia, 26 $34^{\circ}$ 'S, $120^{\circ} 02^{\prime} \mathrm{E}, 08$ May 2001, leg. W. F.Humphreys, C. H. S. Watts \& S. J. B. Cooper (BES 7271); 13. Fifty two males, 60 females and 38 juveniles (WAM C28299 in alcohol), XP1 GWMB, Lake Violet Borefield, Wiluna, Murchison Region, Western Australia, Australia, $26^{\circ} 40^{\prime} \mathrm{S}, 120^{\circ} 14^{\prime} \mathrm{E}, 09$ My 2001 , leg. W. F. Humphreys, C. H. S. Watts \& S. J. B. Cooper (BES 7277); 14. Two females and 3 juveniles (WAM C28300 in alcohol), XP4 GWMB, Lake Violet Borefield, Wiluna, Murchison Region, Western Australia, Australia, $26^{\circ} 41^{\prime} \mathrm{S}, 120^{\circ} 13^{\prime} \mathrm{E}, 09$ May 2001 , leg. W. F. Humphreys, C. H. S. Watts \& S. J. B. Cooper (BES 7278); 15. Two males, 9 females and 9 juveniles (WAM C28301 on slide, C28302 in alcohol), mineral exploration bore near Bubble Well, Millbillillie Station, Wiluna, Murchison Region, Western Australia, Australia, $26^{\circ} 34^{\prime}$ 'S, $120^{\circ} 02^{\prime} \mathrm{E}, 12$ May 2001 , leg. W. F. Humphreys, C. H. S. Watts \& S. J. B. Cooper (BES 7279).

Etymology: The species is named after Dr Dan L Danielopol (Institute of Limnology of the Austrian Academy of Science), in honour to his great contribution to our recent knowledge of zoogegraphy of the genus Candonopsis.

Description of male (Holotype) : Carapace shape subreniform in lateral view (Fig. 38). When seeing from left side RV dorsally clearly overlaps $\mathrm{LV}$ with flange. Dorsal margin on LV flat and slightly inclined towards anterior end (Fig. 39) while RV more equally rounded. Dorsal margin slopping towards frontal margin evenly, while very inclined towards caudal one. Ventral margin concave in middle. $\mathrm{L}=0.925 \mathrm{~mm}$. Greatest $\mathrm{H}$ lies behind middle, equalling $54.4 \%$ of $\mathrm{L}$. In dorsal view (Fig. 40), LV overlaps RV anteriorly and posteriorly. Both ends equally rounded. Greatest W lies around middle, equalling $36 \%$ of L: Marginal zone broader anteriorly ( $22 \%$ of $\mathrm{L})$, than posteriorly ( $17 \%$ of $\mathrm{L})$. Line of concrescence very narrow and with dense marginal pore canals. Valve surface covered with hairs, otherwise smooth and without ornamentation.

A1 7-segmented. First segment with two setae postero-distally, one seta antero-distally and one seta antero-proximally. Second segment with one pappose seta, antero-distally which not reaching distal end of following segment. Third segment with one short seta postero-distally (reaching middle of following segment). Fourth segment with one short seta postero-distally (not reaching middle of following segment) and two setae antero-distally (one just exceeding distal end of penultimate segment, other much longer). Penultimate segment with totally five setae (three long and one 

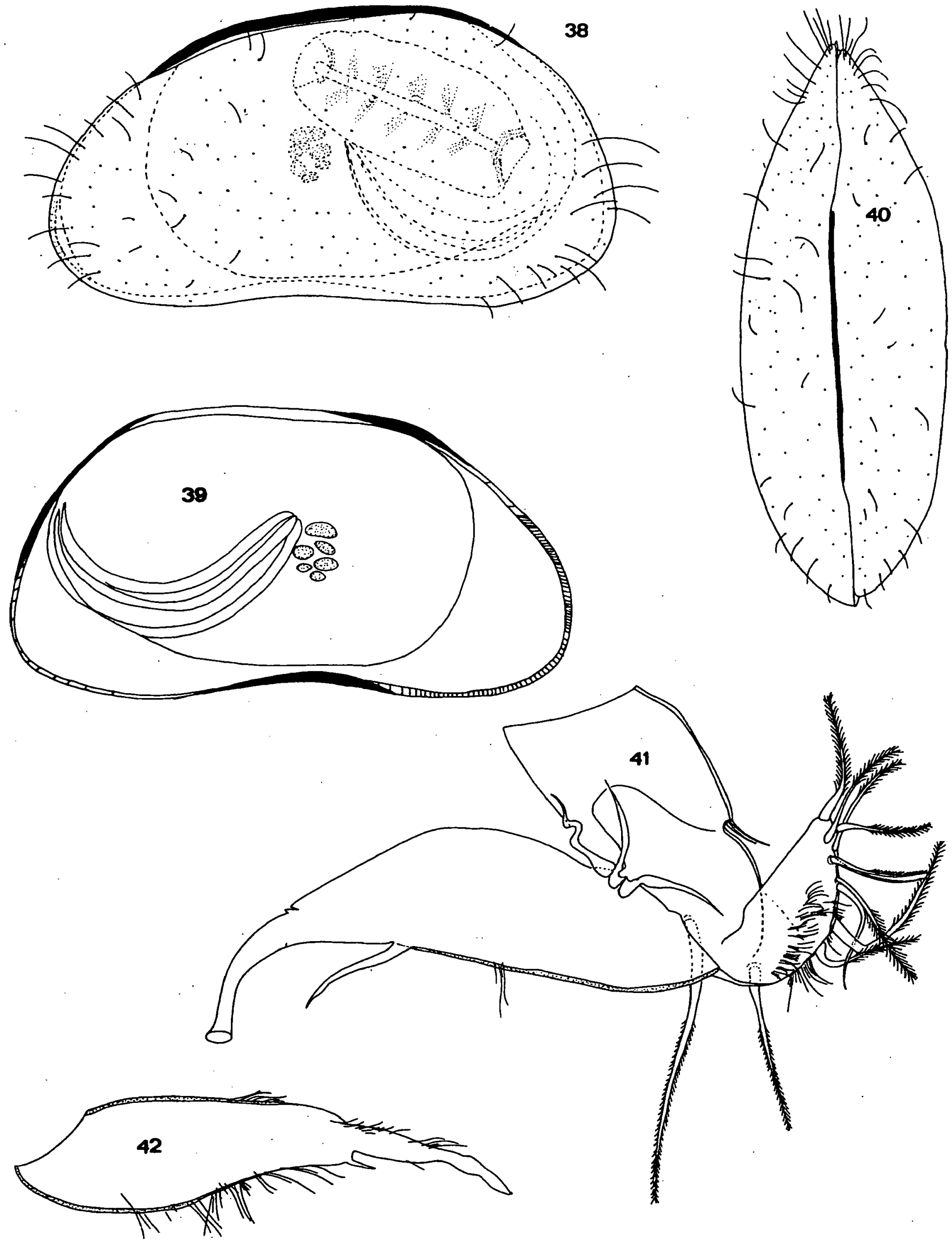

$38-40$

41,42

Figs 38-42. Candonopsis dani $\mathrm{n}$. sp.; holotype (male, $\mathrm{L}=0.925 \mathrm{~mm}$ ): 38-carapace, lateral view; 39-LV, internal view; 40-carapace, dorsal view; 41-T1 with right prehensile palp; 42-left prehensile palp. Scales $=0.1 \mathrm{~mm}$.

Figs 38-42. Candonopsis dani $\mathrm{n}$. sp.; holotype (mâle, $\mathrm{L}=0.925 \mathrm{~mm}$ ): 38-carapace, vue latérale; 39-LV, vue interne; 40-carapace, vue dorsale; 41 T1 avec palpe préhensile droite; 42 -palpe préhensile gauche. Echelle $=0.1 \mathrm{~mm}$. 
(17)
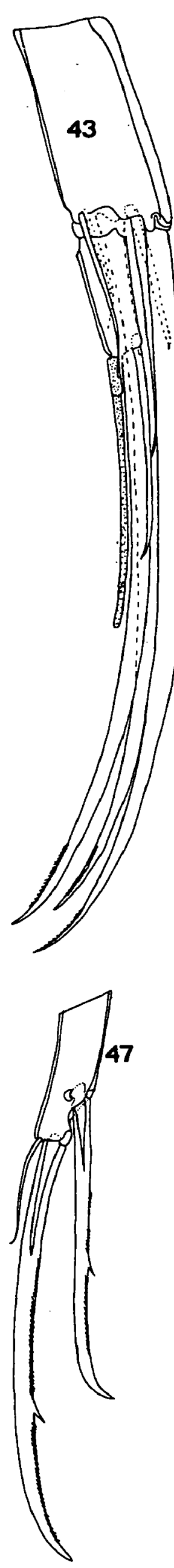

143
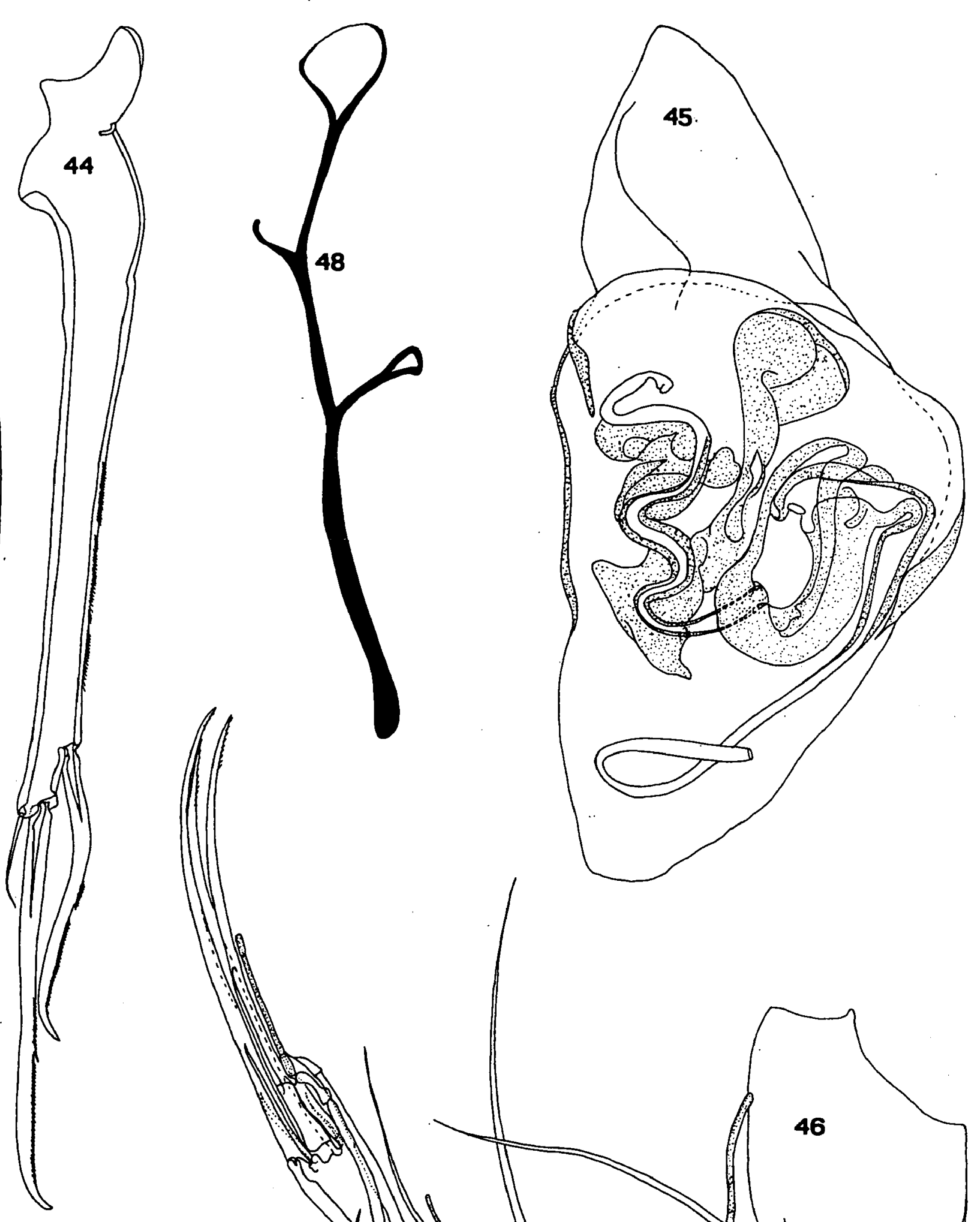

215 

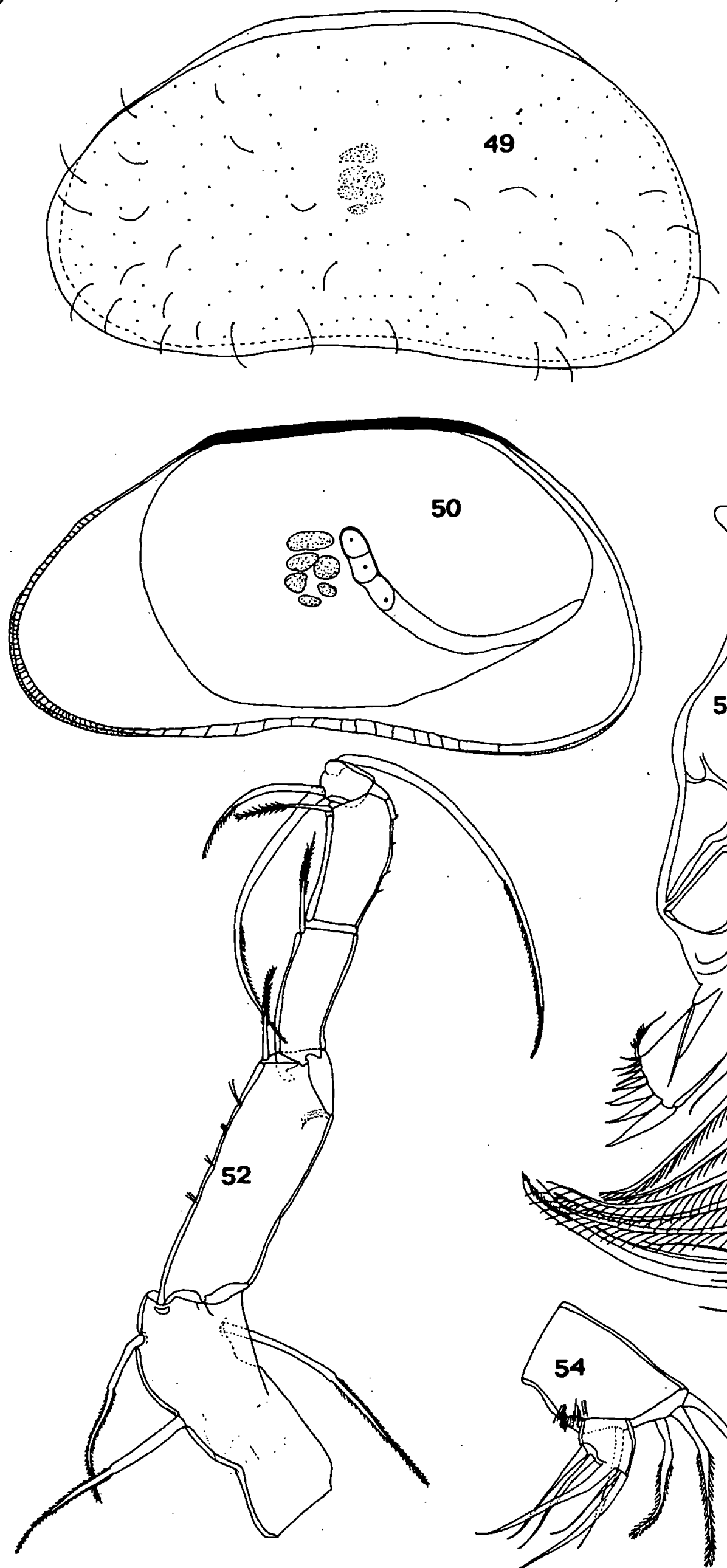

49-51

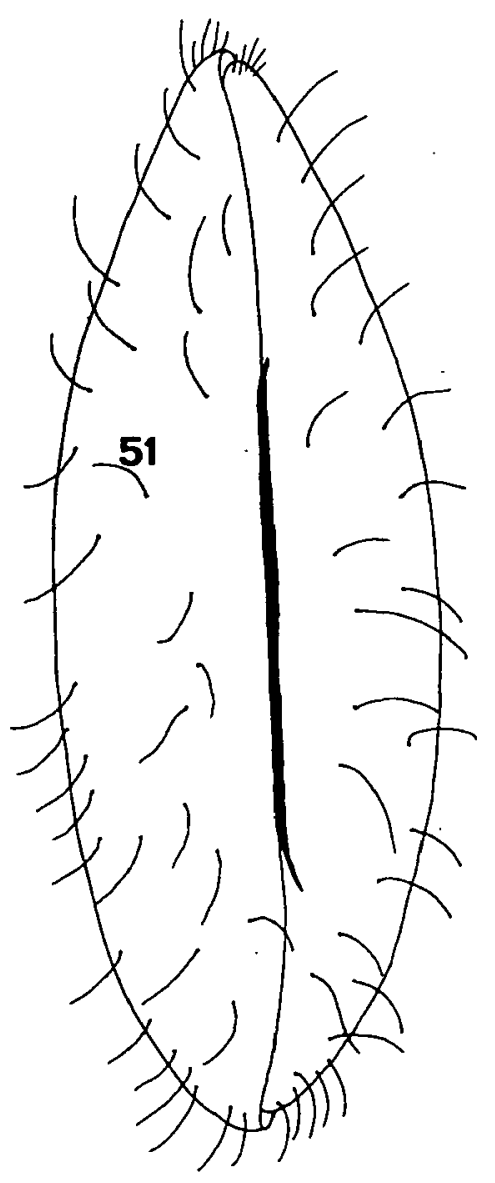

(18) 
(19)

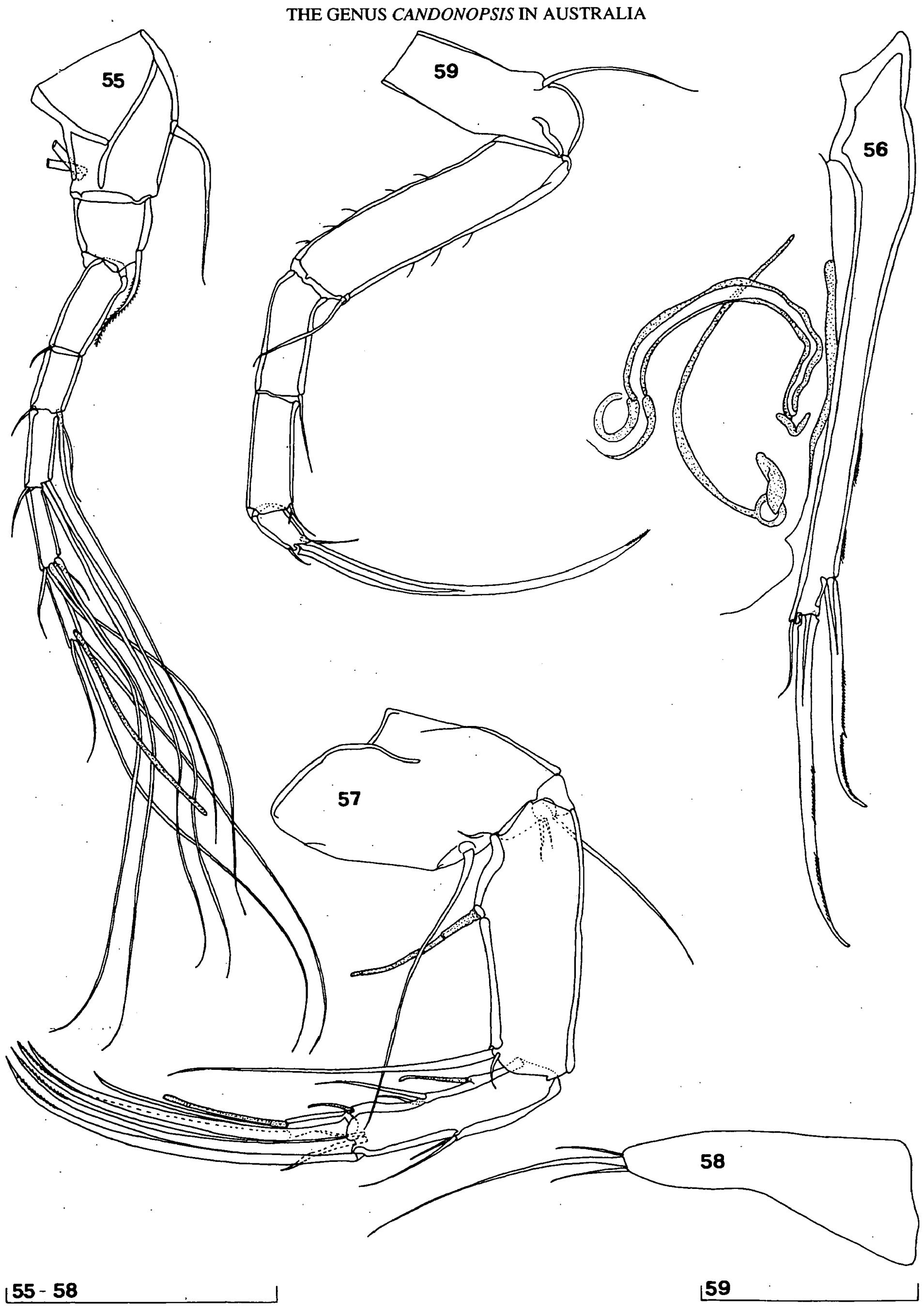


short, alpha seta hardly visible). Terminal segment with aesthetasc, ya, which 3.3 times as long as same segment. $L$ ratios of five distal segments $1.5: 1: 1.3$ : $1.3: 1.2$.

A2 (Figs 43, 46). Males bristles well developed, exopodite with two short and one long seta. Aesthetasc Y 0.46 time as long as first endopodal segment, y1 just slightly exceeding distal end of second endopodal segment, y2 not observed, y3 2.1 times as long as terminal segment. Claw G2, and transformed z2 seta subequally long and 1.2 times as long as first endopodal segment. Caw G1 reduced, claw-like and 1.8 times as long as terminal segment while claw G3 seta-like and 1.2 times as long as terminal segment. Seta $\mathrm{z} 1 \mathrm{1.2}$, while $\mathrm{z} 3$ as long as terminal segment. Claw GM as long as first endopodal segment, $\mathrm{Gm} 1.7$ times as long as terminal segment. L ratios of four endopodal segments $5: 2.3: 1.7: 1$.

Md palp with 3+2 setae in bunch on second segment, two setae externally on same segment; two setae externally, and five setae distally on penultimate segment (gamma seta pappose). L : W ratio of terminal segment 6.5 : 1. Last two segments of subequal L. Terminal segment with fused, distally pappose claw, one seta externally, and two setae internally.

Mxl palp with four pappose setae distally on first segment, terminal segment with six appendages.

T1 with transformed endopodites on prehensile palps, right being (Fig. 41) stronger and with longer subapical structure than left one (Fig. 42). Protopodite with two «a» setae, «b» and «d» setae present.

T2 with one long seta on basal segment, one seta on first endopodal segment (almost reaching distal end of second endopodal segment), following segment with seta which slightly exceeds middle of penultimate segment. Penultimate segment with two small setae, and claw which slightly serrated distally, and 1.2 times as long as three distal segments combined.

T3 five-segmented. All basal setae present, «e» seta pappose and hardly reaching middle of following segment; «f» and «g» setae equally long, pappose. $L$ ratios of three «h» setae on terminal segment $1: 1.9: 2.6$.

Posterior furcal margin (Fig. 44) with rows of fine spines. L ratios of anterior margin, anterior and posterior claws $2.1: 1.4: 1$. Spine well developed just on anterior claw, while on posterior one this spine not clearly distinguishable. Both claws serrated. Anterior seta 4.5 times shorter than anterior claw. Posterior claw «S» shaped. Furcal attachment shown on Fig. 48.

Hemipenis (Fig. 45). Lobe «a» triangular and distally pointed, both «b» and «h» lobes equally rounded.
Description of female (Allotype) : In lateral view (Fig. 49) RV overlapping distinctly LV. L=0.869 $\mathrm{mm}$. Greatest $\mathrm{H}$ lies well behind middle equalling $53 \%$ of $\mathrm{L}$, greatest $\mathrm{W}$ lies around middle equalling $35 \%$ of $\mathrm{L}$. Marginal zone anteriorly $24 \%$ of $\mathrm{L}$, posteriorly $18 \%$ of L. Other characteristics of carapace same as in male.

A2 (Fig. 57) 4-segmented. Aesthetasc Y 0.5 times as long as first endopodal segment, y1 slightly exceeding middle of third endopodal segment, y 2 not reaching distal end of terminal segment, y3 1.9 times as long as terminal segment. All claws well developed and being 1.3 times as long as first endopodal segment. Claw $\mathrm{GM}$ as long as first endopodal segment, $\mathrm{Gm} 3$ times longer than terminal segment. Seta $\mathrm{z} 1$ claw-like and 1.4 times as long as terminal segment. Only two «t» setae visible. $L$ ratios of three endopodal segments 4.36 : 3.3 :

Endopodite T1 (Fig. 58) with two setae of subequal $\mathrm{L}$, and one being much longer.

Fu (Fig. 56) with $\mathrm{L}$ ratios of anterior margin, anterior and posterior claws $2: 1.5: 1$. Spine present just on posterior claw. Both claws serrated. Genital segment rounded and without extensions.

Other appendages (A1, Md, Mxl, T2, T3) same as in male.

Variability: Length of carapace in males varies between $0.915 \mathrm{~mm}$ and $0.945 \mathrm{~mm}$, while in females the length ranges between 0.866 and $0.9 \mathrm{~mm}$. The majority of male specimens have posterior furcal claw «S» formed, but as well there are males with this claw straight, and with one well visible spine on it (Fig. 47).

\subsection{Candonopsis williami n. sp.}

(Figs 60-82)

Material examined : 1. Holotype, male (WAM C28303), allotype, female (WAM C28304), and paratypes: 3 males and 2 juveniles (WAM C28305 on slide, WAM C28306 in alcohol), GSWA 15, Paroo Station, Wiluna, Murchison Region, Western Australia, Australia, 26020'S, 119047'E, 16 May 1999, leg. W. F. Humphreys \& H. J. Hahn (BES 7122); 2. One female and 2 juveniles (WAM C28307 on slide, WAM C28308 in alcohol), GSWA 15(A), Paroo Station, Wiluna, Murchison Region, Western Australia, Australia, $26^{\circ} 24^{\prime} 02^{\prime \prime}$, $119^{\circ} 45^{\prime} 47^{\prime}$ 'E, 09 June 1998, leg. S. M. Eberhard (BES 5989); 3. One juvenile (WAM C28309 in alcohol), GSWA 16, Paroo Station, Wiluna, Murchison Region,

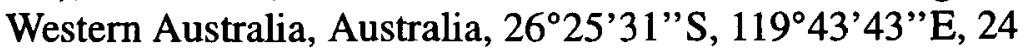
June 1998, leg. S. M. Eberhard (BES 5995); 4. One male, 1 female, 2 juveniles (WAM C28310, C28351 on slides, C28312 in alcohol), GSWA 15(A), Paroo Station, Wiluna, Murchison Region, Western Australia, Australia, $26^{\circ} 24^{\prime} 02^{\prime \prime}$ 'S, $119^{\circ} 45^{\prime} 47^{\prime \prime}$ E, 25 June 1998, leg. S. M. Eberhard (BES 6007); 5. Three males, 1 female and 1 juvenile 
(21)
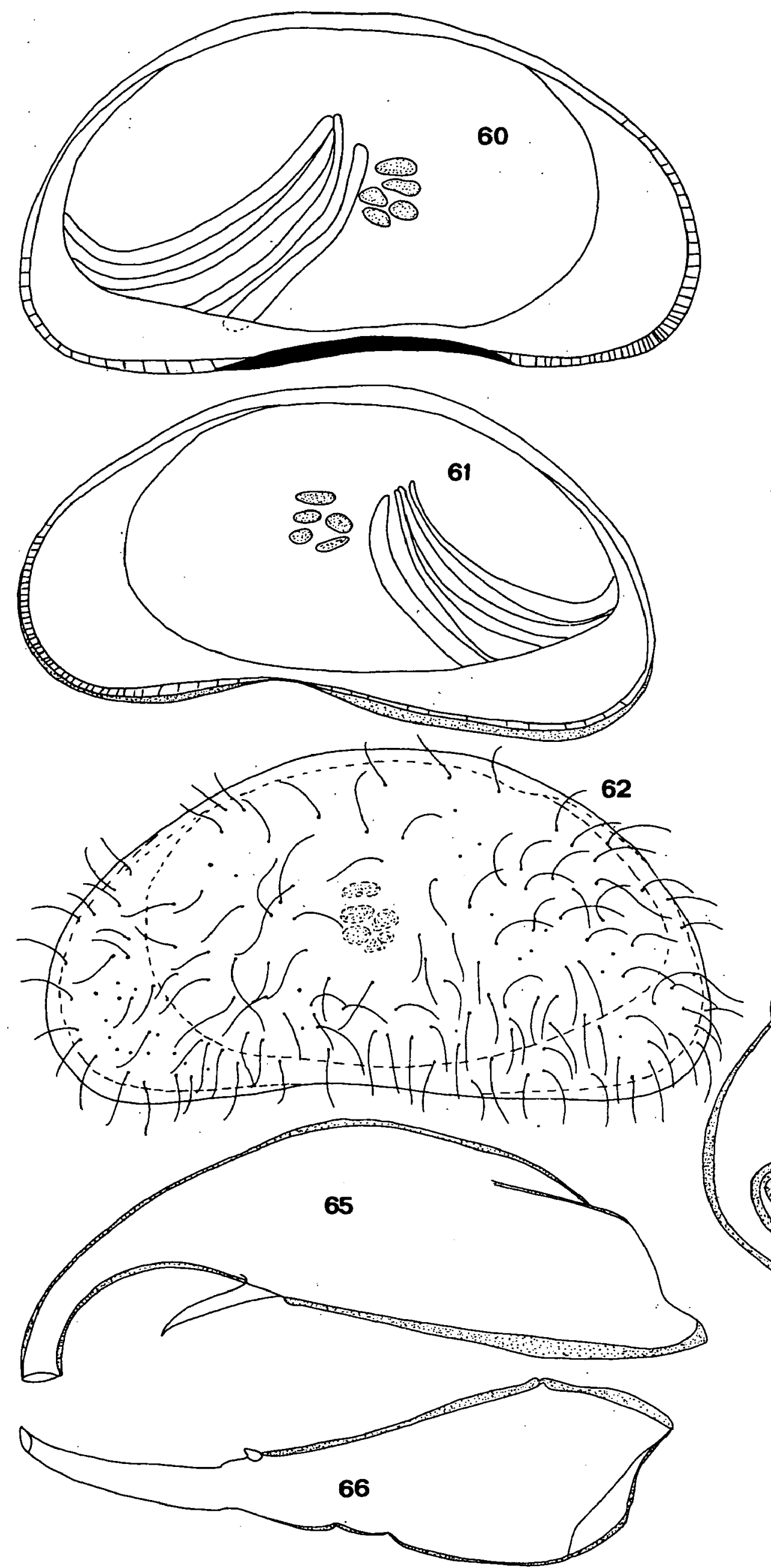

60-63

64-66

Figs 60-66. Candonopsis williami n. sp.; 60, 61, 63-66; holotype (male, $\mathrm{L}=0.637 \mathrm{~mm}$ ); 62, paratype, WAM C28305 (male, L=0.623 mm): 60 LV, internal view; 61-RV, internal view; 62-carapace, lateral view; 63-carapace, dorsal view; 64-hemipenis; 65-right prehensile palp; 66-left prehensile palp. Scales $=0.1 \mathrm{~mm}$.

Figs 60-66. Candonopsis williami $\mathrm{n}$. sp.; 60, 61, 63-66, holotype (mâle, $\mathrm{L}=0.637 \mathrm{~mm}$ ); 62, paratype, WAM C28305 (mâle, L=0.623 mm): 60 LV, vue interne; 61-RV, vue interne; 62-carapace, vue latérale; 63-carapace, vue dorsale; 64-hémipénis; 65-palpe préhensile droit; 66-palpe préhensile gauche. Echelle $=0.1 \mathrm{~mm}$. 


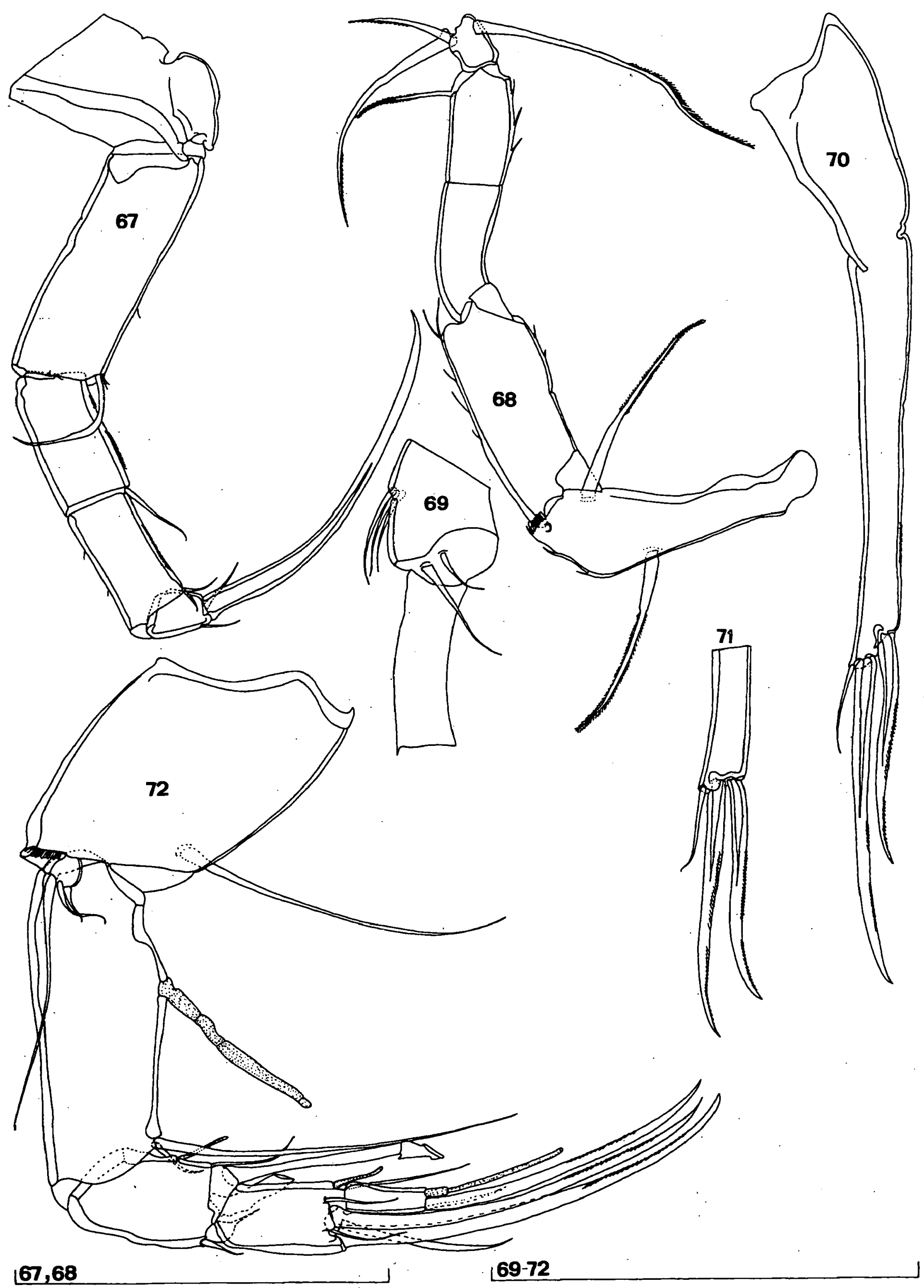

(22) 
(23)

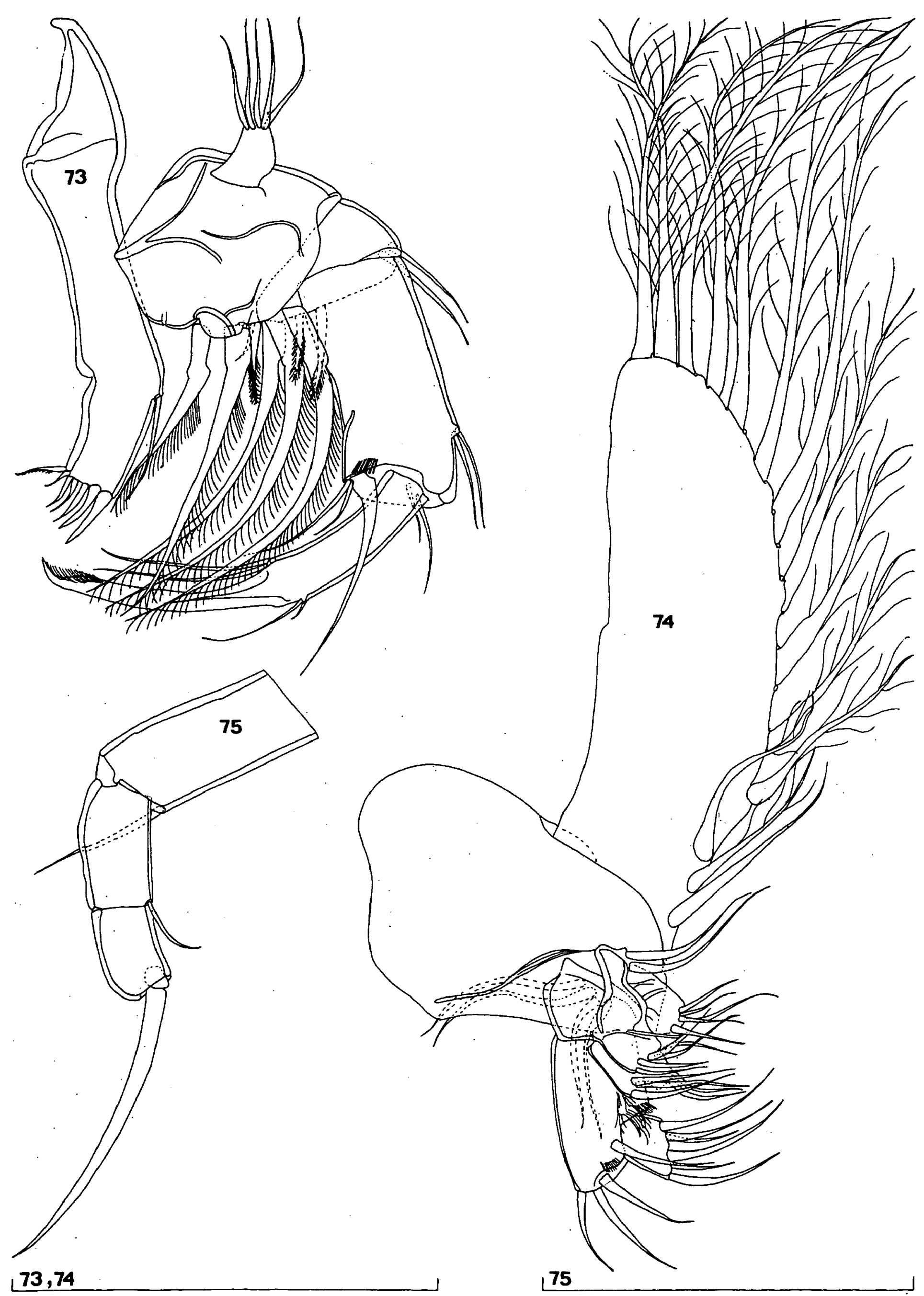

Figs 73-75. Candonopsis williami $\mathrm{n}$. sp.; 73, 74, allotype (female, L = 0.627 mm); 75, WAM C28355 (female, L = 0.572 mm): 73-Md; 74-Mxl; 75-T2. Scales $=0.1 \mathrm{~mm}$.

Figs 73-75. Candonopsis williami $\mathrm{n}$. sp.; 73, 74, allotype (femelle, L = 0.627 mm); 75, WAM C28355 (femelle, L = 0.572 mm): 73-Md; 74-Mxl; 75-T2. Echelle $=0.1 \mathrm{~mm}$. 


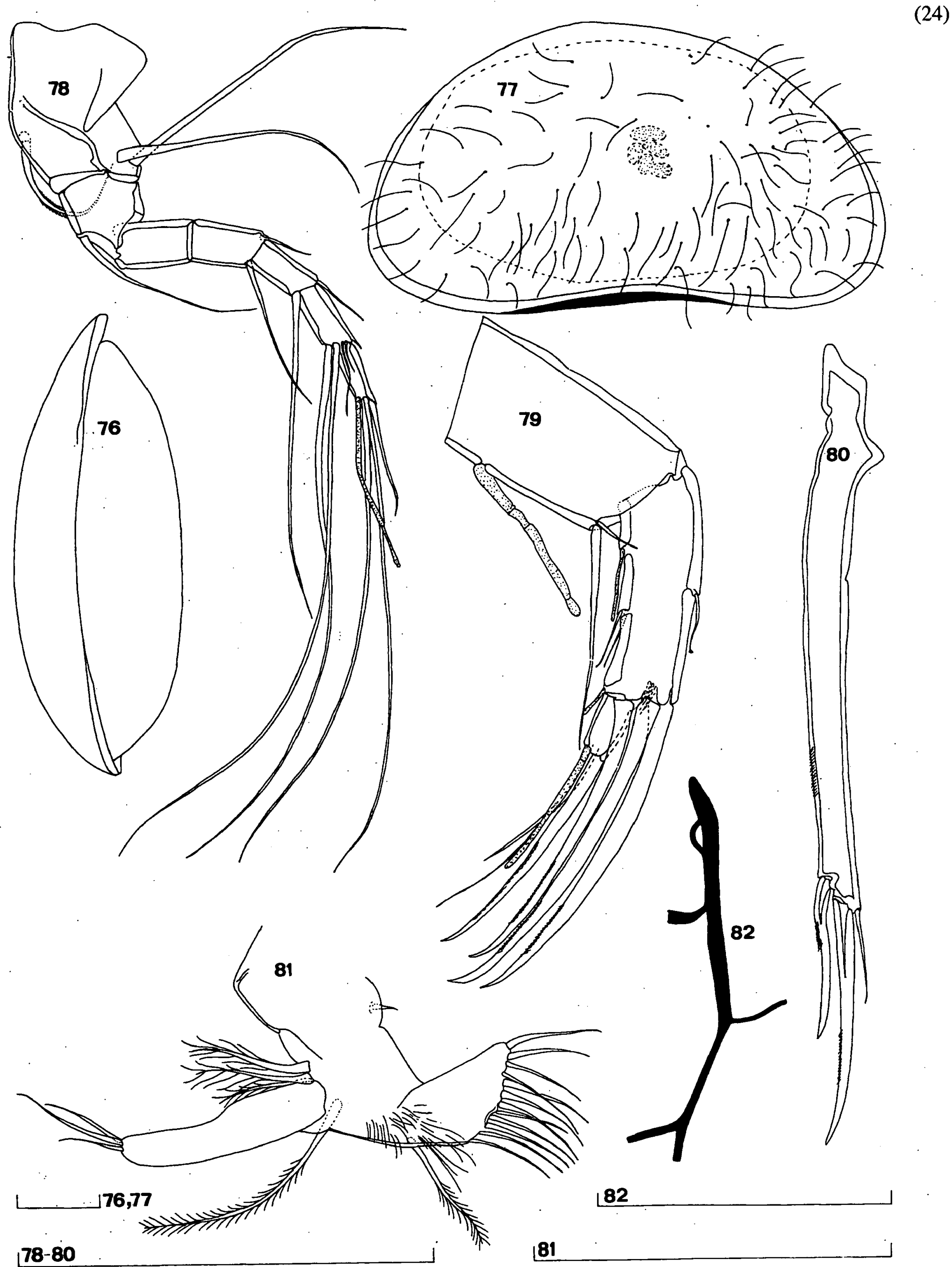


(WAM C28352, C28353 on slides, C28354 in alcohol), GSWA 6(C), Paroo Station, Wiluna, Murchison Region, Western Australia, Australia, 26⒉ $24^{\prime} 02^{\prime \prime}$ 'S, $119^{\circ} 45^{\prime} 47^{\prime \prime} \mathrm{E}, 25$ June 1998, leg. S. M. Eberhard (BES 6023); 6. One female (WAM C28355 on slide), GSWA 6, Paroo Station, Wiluna, Murchison Region, Western Australia, Australia, $26^{\circ} 20^{\prime} \mathrm{S}$, $119^{\circ} 47^{\prime} \mathrm{E}, 15$ May 1999 , leg. W. F. Humphreys \& H. J. Hahn (BES 7094); 7. One male (WAM C28356 in alcohol), GSWA 6, Paroo Station, Wiluna, Murchison Region, Western Australia, Australia, $26^{\circ} 20^{\prime} \mathrm{S}, 119^{\circ} 47^{\prime} \mathrm{E}, 15$ May 1999 , leg. W. F. Humphreys \& H. J. Hahn (BES 7093); 8. One female (WAM C28357 in alcohol), GSWA 15, Paroo Station, Wiluna, Murchison Region, Western Australia, Australia, $26^{\circ} 24^{\prime} \mathrm{S}$, $119^{\circ} 46^{\prime}$ E, 07 May 2001, leg. W. F. Humphreys, C. H. S. Watts \& S. J. B. Cooper (BES 5619); 9. Two females (WAM C28359 in alcohol), GSWA 5, Paroo Station, Wiluna, Murchison Region, Western Australia, Australia, $26^{\circ} 25^{\prime} \mathrm{S}$, $119^{\circ} 44^{\prime}$ E, 07 May 2001, leg. W. F. Humphreys, C. H. S. Watts \& S. J. B. Cooper (BES 5630).

Etymology : The species is named after Dr William F. Humphreys (Western Australian Museum), who collected most of the Candonopsis material in Australia.

Description of male (Holotype) : Carapace in lateral view (Figs 60, 61) reniform. Dorsal margin evenly rounded, evenly slopping towards both frontal and caudal margins. Both margins rounded, frontal one being slightly wider than caudal. Ventral margin concave in middle. $\mathrm{L}=0.637 \mathrm{~mm}$, greatest $\mathrm{H}$ situated slightly behind middle, equalling $54 \%$ of $\mathbf{L}$. In dorsal view (Fig. 63) LV overlapping RV on both anterior and posterior ends. Both ends equally rounded. Greatest W lies around middle, being $40 \%$ of L. Marginal zone anteriorly $17.7 \%$, posteriorly $11 \%$ of L. Line of concrescence narrow and with short, dense canals. Selvage peripheral, visible on RV. Valve surface covered with hairs, otherwise not ornamented.

A1 7-segmented. First segment with two setae postero-distally, one seta antero-distally, and one seta antero-proximally. Second segment with one seta anterodistally (reaching distal end of fourth segment), third segment without any seta, following two segments each with one seta antero-distally and one seta posterodistally. Penultimate segment with totally five setae (alpha seta hardly visible and not shown on Fig. 78). Terminal segment with aesthetacs which 2.9 times as long as terminal segment. All endopodal segment of almost equal $\mathrm{L}$.

A2 (Fig. 72), 5-segmented and with well developed male's sexual bristles. Exopodite with two short and one long seta. Aesthetasc Y 0.6 times as long as first endopodal segment, $y 1$ reaching distal end of second endopodal segment, y2 not reaching middle of terminal segment, y3 two times as long as terminal segment.
Claw G2 and transformed seta $\mathrm{z} 21.2$ times as long as first endopodal segment. Claw G1 reduced and 2.2 times as long as terminal segment, while G3 seta-like and 1.7 times as long as same segment. Both $\mathrm{z} 1$ and $\mathrm{z} 3$ setae as long as terminal segment. $L$ ratios of four endopodal segments $4.2: 1.8: 1.6: 1$.

Md with 3+2 setae in bunch on second segment, two setae externally on same segment. Penultimate segment with two setae extero-distally, and five setae distally. $\mathrm{L}: \mathrm{W}$ ratio of terminal segment $4: 1$. Same segment with fused claw (pappose distally), one seta externally and two setae internally. $L$ ratio of subterminal and terminal segment $1.2: 1$.

Mxl palp with four pappose setae distally on first, and six appendages on terminal segment.

Prehensile palps asymmetrical, right (Fig. 65) with longer subapical structure, than on left one (Fig. 66). Just one «a» seta developed on protopodite, setae «b» and «d» present.

T2 5-segmented (Fig. 67). Basal segment without any seta. First endopodal segment with one seta distally, which exceeds distal end of second endopodal segment. Following segment with one seta which exceeds middle of penultimate segment. Penultimate segment with two small setae. Terminal segment with two setae and claw, which smooth and 1.12 times as long as three distal segments combined.

T3 5-segmented (Fig. 68). Basal segment with just d1 and dp setae present, while d2 seta missing. Both setae pappose. First endopodal segment without any seta distally. On second endopodal segment «f» seta also missing, while «g» seta on penultimate segment pappose and as long as same segment. Terminal segment with $L$ ratio of $h 1, h 2$, and $h 3$ setae as follows 1 : $2.2: 3$. All three setae pappose.

Fu (Fig. 70) with just one row of small and tiny spines on posterior end. Neither of furcal claws with spine, both serrated. L ratios of anterior margin, anterior and posterior claws $2.5: 1.44: 1$. Anterior seta 3.6 times shorter than anterior claw.

Hemipenis (Fig. 64) lobe «a» triangular, but with maximum width at one third of its length, also pointed distally, and stocky in appearance. Both «b» and «h» lobes rounded.

Description of female (Allotype) : Carapace in lateral appearance (Fig. 77) same as in male: reniform, with evenly rounded dorsal margin. $\mathrm{L}=0.627 \mathrm{~mm}$. Greatest $\mathrm{H}$ lies slightly behind middle equalling $56 \%$ of L. Greatest W 35\% of L. Other details of carapace same as in male. 
A2 (Fig. 79) 4-segmented. Aesthetasc Y 0.66 times as long as first endopodal segment, y1 reaching middle of second endopodal segment, y2 reaching middle of terminal segment, while y3 2.4 times as long as same segment. Only two «t» setae developed. All three claws on penultimate segment well developed and 1.25 times as long as first endopodal segment. All z setae small, and just half as long as terminal segment. Claw Gm 0.9 times as long as first endopodal segment, Gm 2.5 times longer than terminal segment. $L$ ratios of three endopodal segments as follows $4.4: 1.7: 1$.

Endopodite of T1 (Fig. 81) with three setae apically, $\mathrm{L}$ ratios $1: 1.7: 1.3$.

Fu (Fig. 80) like in male with just one row of fine spines on posterior margin. $L$ ratios of anterior furcal margin, anterior and posterior claws as follows 2.7 : $1.5: 1$. Neither of claws carry spines, but both serrated. Genital lobe rounded and without extensions. Furcal attachment shown on Fig. 82.

Other appendage : A1, Md, Mxl, T2 and T3 same as in male.

Variability : Length of males varies between 0.619 $\mathrm{mm}$ and $0.637 \mathrm{~mm}$, while in females between $0.57 \mathrm{~mm}$ and $0.632 \mathrm{~mm}$. There are a lot of other varibilities recorded in this species, that could be rather called anomalies. In one male (Fig. 62) terminal furcal claws are of almost the same length (Fig. 71), while in all other males posterior claw is clearly shorter than anterior one. Same male has three setae extero-distally on penultimate segment of Md palp (Fig. 69), while in all other specimens there are always two setae. In one female (Fig. 76), one of T2 is completely deformed with small terminal segment (Fig. 75), and without seta on third endopodal segment, while other $\mathrm{T} 2$ is as in all other specimens.

\subsection{Caindonopsis kimberleyi n. sp.}

(Figs 83-99)

Material examined : 1. Holotype, male (WAM C28359), Wagon Pass drill hole NRD 114, Kimberley, Western Australia, Australia, $17^{\circ} 10^{\prime} 31^{\prime \prime} \mathrm{S}, 124^{\circ} 37^{\prime} 56^{\prime \prime}, 17$ July 1998, leg. S. M. Eberhard (BES 6112), allotype, female (WAM C28360), paratypes : 1 female, 1 juvenile (WAM C28361 in alcohol); 2 . One juvenile male, 1 juvenile female (WAM C28362, C28363 on slides), Wagon Pass drill hole NRD 82,

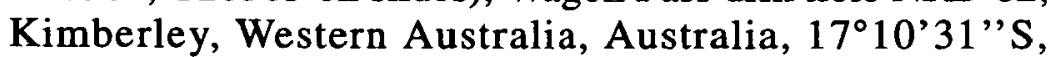
$124^{\circ} 37^{\prime} 50^{\prime \prime}, 17$ July 1998, leg. S. M. Eberhard (BES 6123).

Etymology : The specific name is derived from the region where it was collected (Kimberley).

Description of male (Holotype) : Valve shape in lateral view trapezoidal (Fig. 83, 84). Dorsal margin flat to slightly concave around middle, than slopping evenly towards frontal, and more inclined towards caudal margin. Frontal margin wider than caudal one. Both margins rounded. Ventral margin almost straight. $L$ of carapace equals $0.792 \mathrm{~mm}$. Greatest $\mathrm{H}$ situated on posterior end, equalling $50 \%$ of L. Marginal zone narrow, anteriorly just $8 \%$, posteriorly $5 \%$ of L. Line of concrescence narrow with short and dense pore canals. Valve surface very ornamented with irregular, but shallow pits. Also, valve surface covered with hairs.

A1 (Fig. 91) 7-segmented. First segment with one seta antero-proximally, one seta antero-distally, and two setae postero-distally, all pappose. Second segment with also pappose seta antero-distally (reaching distal margin of fourth segment). Third segment without any setae. Fourth segment with two setae distally (anterior one being pappose). Fifth segment with two long setae antero-distally, and one short seta (reaching middle of following segment) postero-distally. Penultimate segment with totally five setae, alpha very short. Terminal segment with two long setae, one short seta, and aesthetasc (ya) which 1.6 times as long as terminal segment. $L$ ratios of five distal segments as follows $1.2: 1: 1: 1: 1.2$.

A2 (Fig. 92) 5-segmented and with well developed male's bristles. Exopodite consists of one long and two short setae. Aesthetasc Y being 0.6 times as long as first endopodal segment, y1 just slightly exceeding distal end of third segment, y2 exceeding distal end of terminal segment, y3 two times as long as terminal segment. Claw $\mathrm{G} 2$ being well developed and 1.2 times as long as first endopodal segment, seta $\mathrm{z} 2$ transformed and as long as first endopodal segment. Claws G1 and $\mathrm{G} 3$ reduced, first one being claw-like and 1.8 times as long as terminal segment, latter one seta-like and 1.2 times as long as same segment. Seta $\mathrm{z} 1$ transformed into short claw which 0.7 times as long as terminal segment, while seta $\mathrm{z} 3$ seta-like and 1.2 times as long as same segment. Claw GM 0.9 times as long as first endopodal segment, $\mathrm{Gm}$ thin and 1.4 times as long as terminal segment. $\mathrm{L}$ ratios of four endopodal segments $4.4: 2.3: 2: 1$.

Md (Fig. 86) with 3+2 setae in bunch and two setae on outer side of same segment. Penultimate segment with two setae extero-distally and four setae distally. $\mathrm{L}$ : W ratio of terminal segment $4.4: 1$. Terminal segment with one distally pappose and fused claw. $\mathrm{L}$ ratio of penultimate and terminal segment $1.1: 1$.

Mxl palp (Fig. 88) with four setae distally on first segment, and only five appendages observed on terminal segment. 
(27)

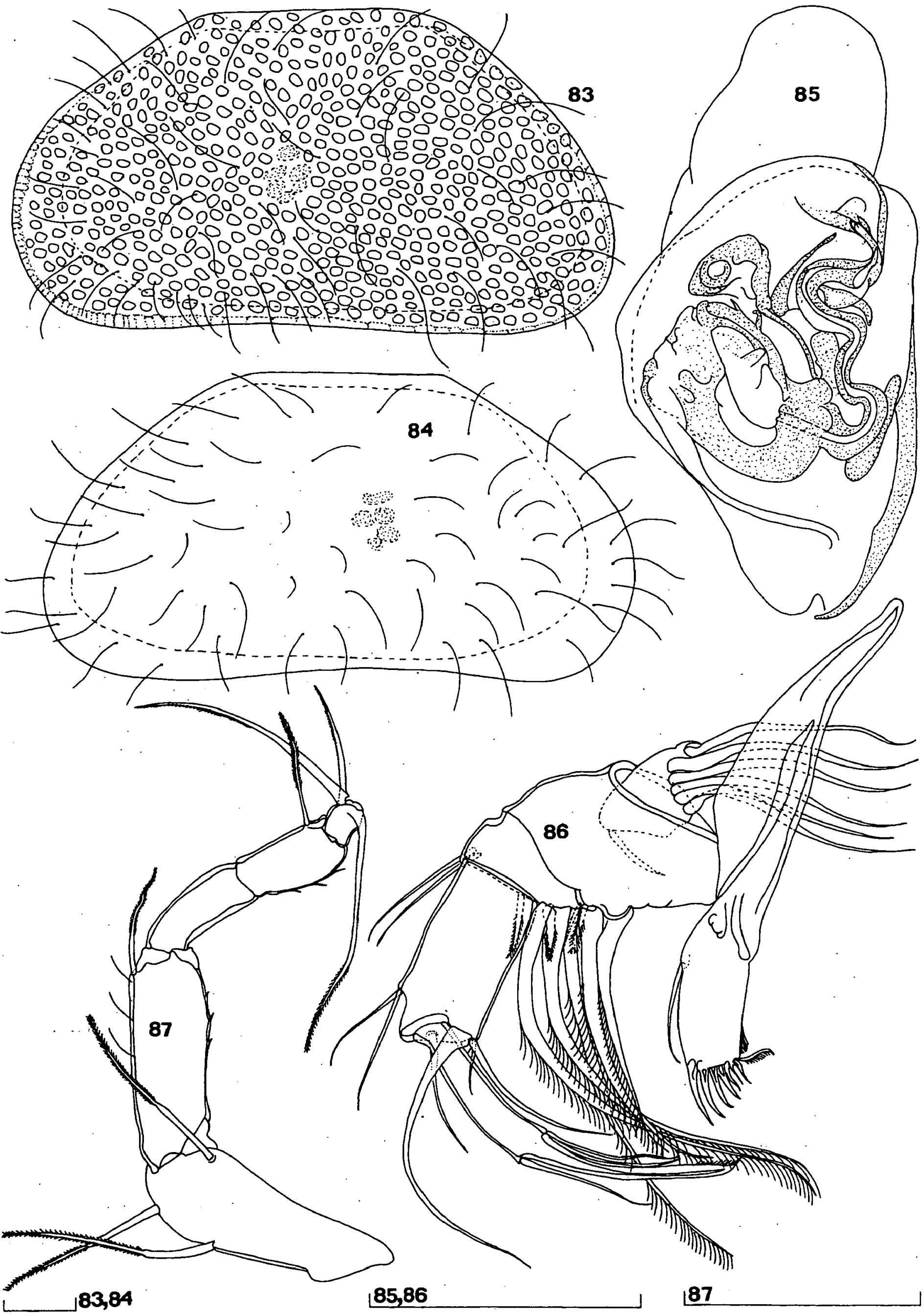

igs 83-87. Candonopsis kimberleyi $\mathrm{n}$. sp.; holotype (male, L = 0.792 mm): 83-LV, external view; 84-RV, external view; 85-hemipenis; 86-Md; 87-T3. Scales $=0.1 \mathrm{~mm}$.

Figs 83-87. Candonopsis kimberleyi n. sp.; holotype (mâle, L = $0.792 \mathrm{~mm}$ ): 83-LV, vue externe; 84-RV, vue externe; 85-hémipénis; 86-Md; 87T3. Echelle $=0.1 \mathrm{~mm}$. 

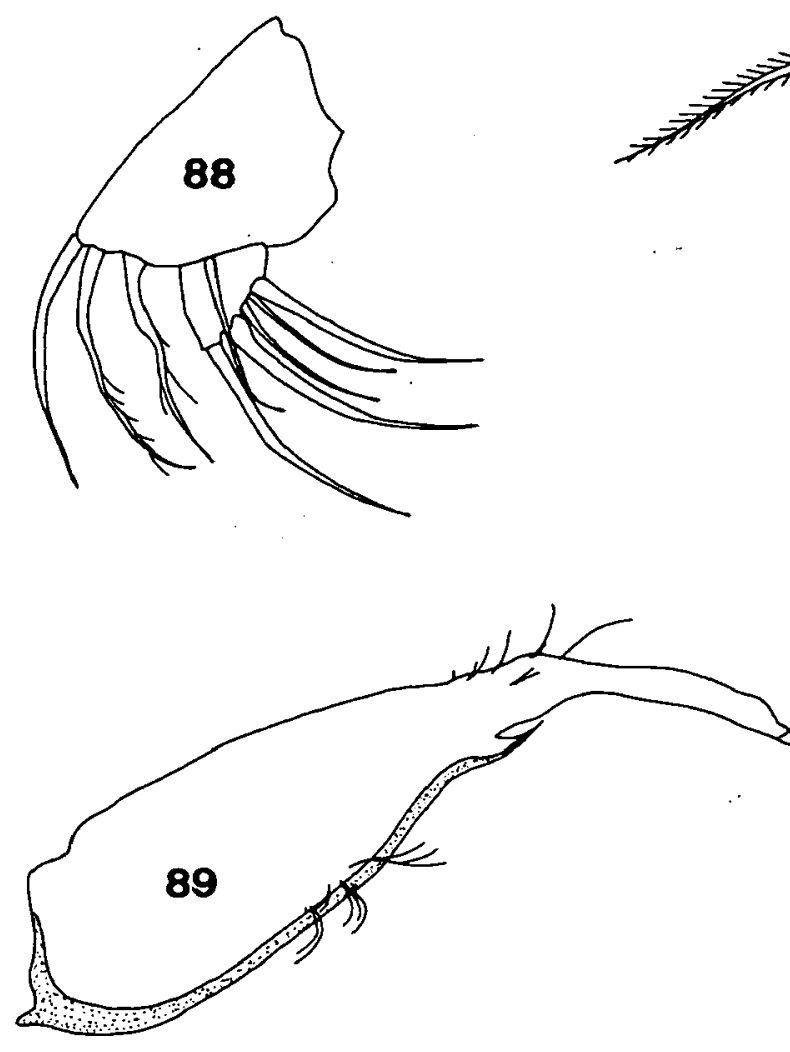
(29)

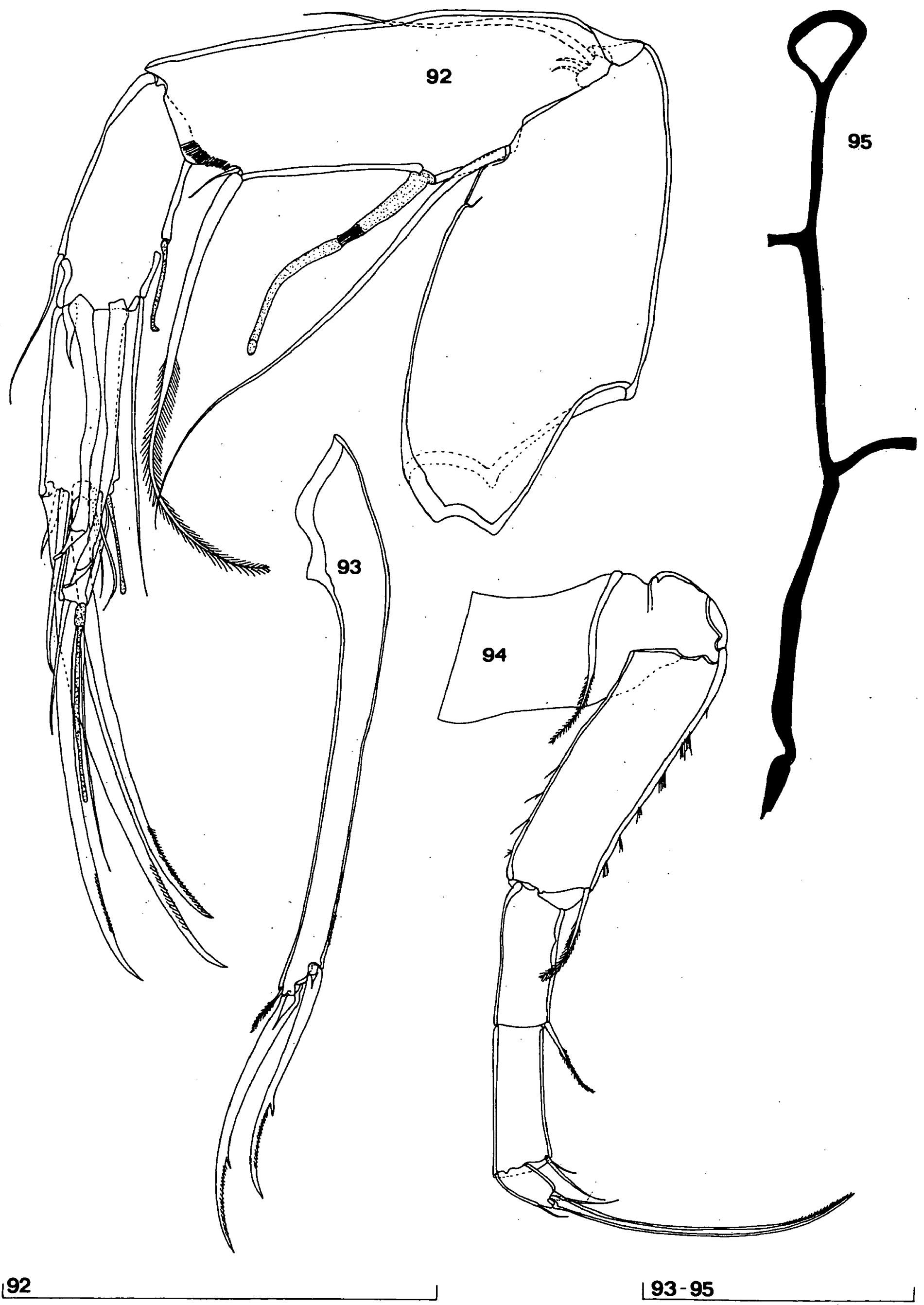

Figs 92-95. Candonopsis kimberleyi $\mathrm{n}$. sp.; holotype (male, $\mathrm{L}=0.792 \mathrm{~mm}$ ): 92-A2; 93-Fu; 94-T2; 95-furcal attachment. Scales $=0.1 \mathrm{~mm}$. Figs. 92-95. Candonopsis kimberleyi n. sp.; holotype (mâle, L=0.792 mm): 92-A2; 93-Fu; 94-T2; 95- attache de la furca. Echelle = $0.1 \mathrm{~mm}$. 


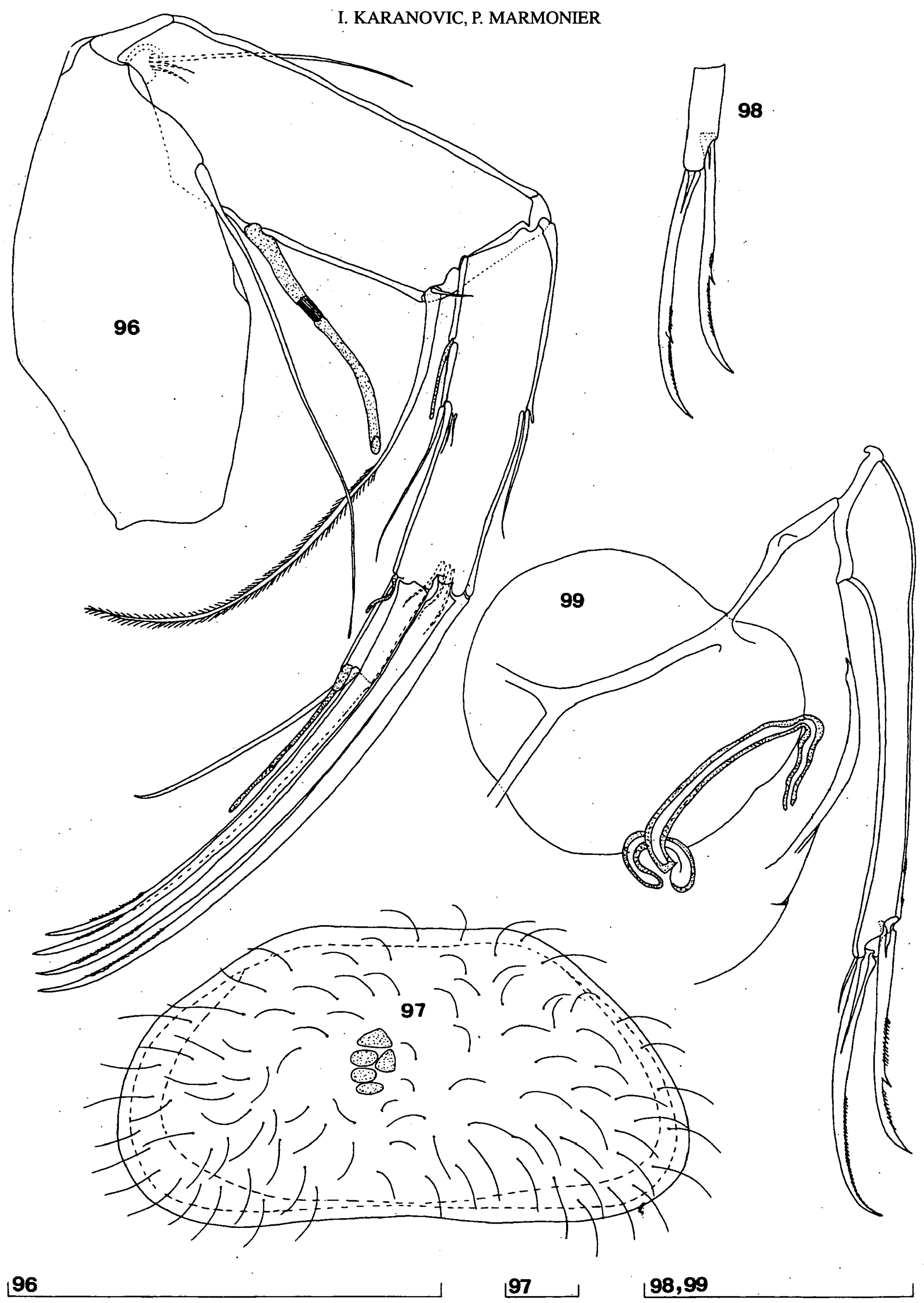


T1 with transformed endopodites of which right one with longer finger and subapical sclerified structure (Fig. 90) and curved dorsal margin, while left one with short seta and with flatter dorsal margin (Fig. 89). Just one «a» seta developed on protopodite, «b» and «d» setae present.

T2 (Fig. 94) 5-segmented. Basal segment with one pappose seta. First endopodal segment with one pappose seta which reaches middle of following segment. Third endopodal segment also with one pappose seta which reaches middle of penultimate segment. Penultimate segment with two short, smooth setae. Terminal segment with two setae and claw which distally serrated and 0.9 times as long as three endopodal segments combined.

T3 (Fig. 87) 5-segmented. Basal segment with all three setae developed, all being pappose. First endopodal segment with «e» seta which slightly exceeds middle of following. segment. Second endopodal segment without any seta, while penultimate one with «g» seta which pappose and longer than same segment. L ratio of «h»-setae on terminal segment $1: 1.9: 2.1$. All setae pappose.

Fu (Fig. 93) with spines developed on both claws, also claws serrated. Posterior margin with two rows of fine spines. $L$ ratio of anterior margin, anterior and posterior claws as follows $1.7: 1.2: 1$. Anterior seta pappose and five times shorter than anterior claw. Furcal attachment shown on Fig. 95.

Hemipenis (Fig. 85) with «a» lobe rounded distally, «b» and «h» lobes also rounded.

Description of female (Allotype) : Carapace in lateral view (Fig. 97) trapezoidal and with slightly concave dorsal margin. Both frontal and caudal margins rounded, frontal being wider than caudal one. $L$ of carapace $0.781 \mathrm{~mm}$. Greatest $\mathrm{H}$ lies on last third and equals $51 \%$ of $\mathrm{L}$. Other characteristics of carapace, as well as ornamentation, same as in male.

A2 with developed three «t» setae on penultimate segment (Fig. 96). Aesthetasc Y being 0.6 times as long as first endopodal segment, $y 1$ reaching middle of third endopodal segment, $\mathrm{y} 2$ hardly reaching middle of terminal segment, y3 1.7 times as long as terminal segment. All three $\mathrm{G}$ claws well developed, being 1.3 times as long as first endopodal segment; claw GM as long as same segment, while $\mathrm{Gm} 2.4$ times as long as terminal segment. All three $\mathrm{z}$ setae of subequal $\mathrm{L}$ and 0.65 times as long as terminal segment. $L$ ratios of three endopodal segments $4: 3.5: 1$.

One Fu (Fig. 99) with just spine on posterior claw, while other with spines on both claws (Fig. 98). Both claws serrated. $L$ ratios of anterior margin, anterior, and posterior claws $1.6: 1.1: 1$. Genital segment rounded and without appendages.

Appearance of $\mathrm{A} 1, \mathrm{Md}, \mathrm{Mxl}, \mathrm{T} 2$ and $\mathrm{T} 3$ same as in male.

\subsection{Candonopsis westaustraliensis n. sp. (Figs 100-117)}

Material examined : 1. Holotype, male (WAM C28364), allotype, female Female (WAM C28365), paratypes: 2 females, 3 juveniles (WAM C28366 in alcohol), Bore at shearing quarters, Depot Springs Station, Murchison Region, Western Australia, Australia, $27^{\circ} 56^{\prime} \mathrm{S}, 120^{\circ} 05^{\prime} \mathrm{E}, 26$ June 2000 , leg. W. F. Humphreys \& S. Hinze (BES 7907); 2. One male, 1 female (WAM C28367 in alcohol), Friday Well, Depot Springs Station, Murchison Region, Western Australia, Australia, $280^{\circ} 3^{\prime} 36^{\prime \prime}, 120^{\circ} 04^{\prime} 03^{\prime} \mathrm{E}, 28 \mathrm{June} 2000$, leg. W. F. Humphreys and S. Hinze (BES 8410); 3. One male, 1 female, 1 juvenile (WAM C28368 in alcohol), Friday Well, Depot Springs Station, Murchison Region, Western Australia, Australia, 2803'36'S, $120^{\circ} 04^{\prime} 03^{\prime \prime} \mathrm{E}, 14$ May 2001, leg. W. F. Humphreys, C. H. S. Watts \& S. J. B. Cooper (BES 6649); 4. One female (WAM C28369 in alcohol), Yuimmery, New Well, Murchison Region, Western Australia, Australia, $28^{\circ} 33^{\prime}$ S, $119^{\circ} 05^{\prime} \mathrm{E}, 15$ May 2001, leg. W. F. Humphreys, C. H. S. Watts \& S. J. B. Cooper (BES 7280).

Etymology : The specific name is derived from «Western Australia», in the apposition to the generic name.

Description of male (Holotype) : Valve in lateral view subreniform (Fig. 100). Dorsal margin inclined towards frontal margin, but flat, than slightly sinusoid. Dorsal margin widely rounded towards caudal end. Caudal margin clearly wider than frontal one. Ventral margin concave around middle. $\mathrm{L}$ of carapace 0.694 $\mathrm{mm}$. Greatest $\mathrm{H}$ lies on last third of $\mathrm{L}$, equalling $50 \%$ of L. In dorsal view (Fig. 102) LV overlaps RV, but slightly, both on anterior and posterior ends. Anterior end also slightly narrower than caudal one. Maximum W around middle, equalling 33\% of L. Marginal zone wide, anteriorly $19 \%$, posteriorly $15 \%$ of $\mathrm{L}$. Line of concrescence very narrow, except in ventral part (Fig. 101 ), and with short and dense marginal pore canals. Selvage peripheral. Valve surface covered with very small, hardly visible and shallow pits. Also, valve surface covered with hairs, longer on posterior end.

A1 (Fig. 105) 7-segmented. First segment with two long postero-distal setae, one seta antero-proximally (not shown on Fig. 105) and one seta antero-distally. Second segment with antero-distal seta which reaches distal end of fourth segment. Third segment with one short seta postero-distally (not reaching distal end of following segment). Fourth segment with short seta 

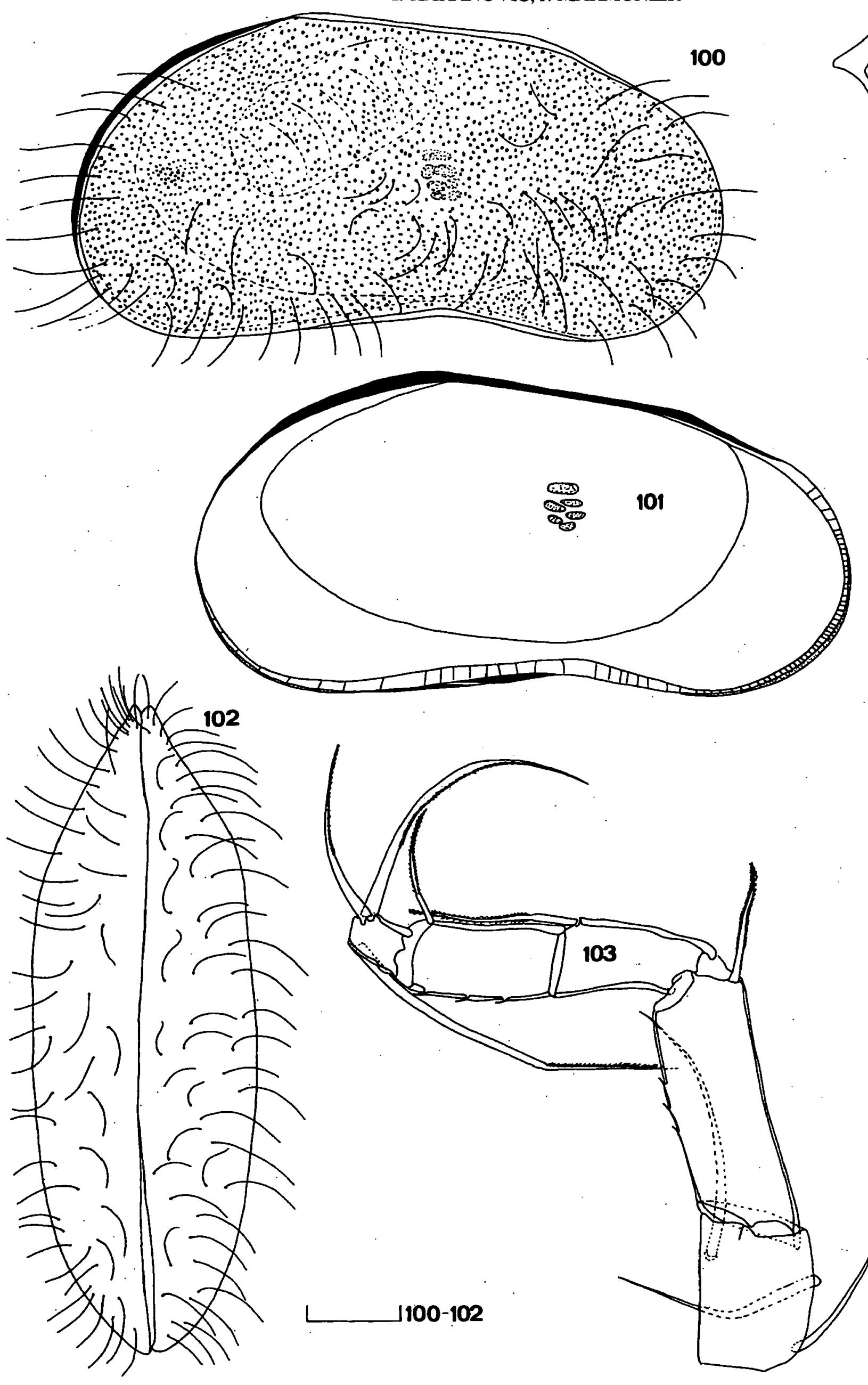
(33)

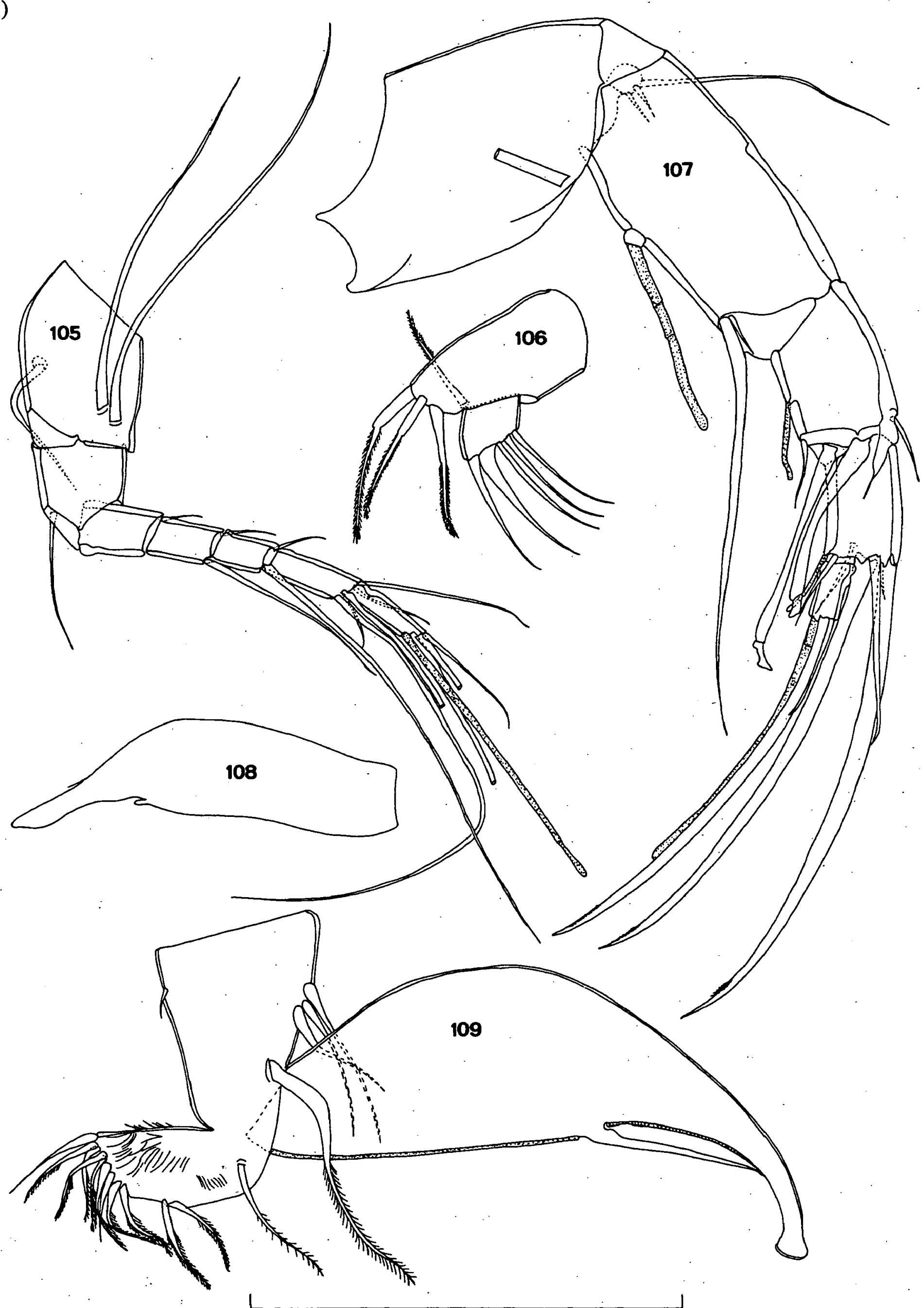

Figs. 105-109. Candonopsis westaustraliensis $\mathrm{n}$. sp.; holotype (male, $\mathrm{L}=0.694 \mathrm{~mm}$ ): 105-A1; 106-Mxl palp; 107-A2; 108-left prehensile palp; 109-T1 with right prehensile palp. Scale $=0.1 \mathrm{~mm}$.

Figs. 105-109. Candonopsis westaustraliensis n. sp.; holotype (mâle, L = 0.694 mm): 105-A1; 106-palpe Mxl; 107-A2; 108-palpe préhensile gauche; 109-T1 avec palpe préhensile droit. Echelle $=0.1 \mathrm{~mm}$. 

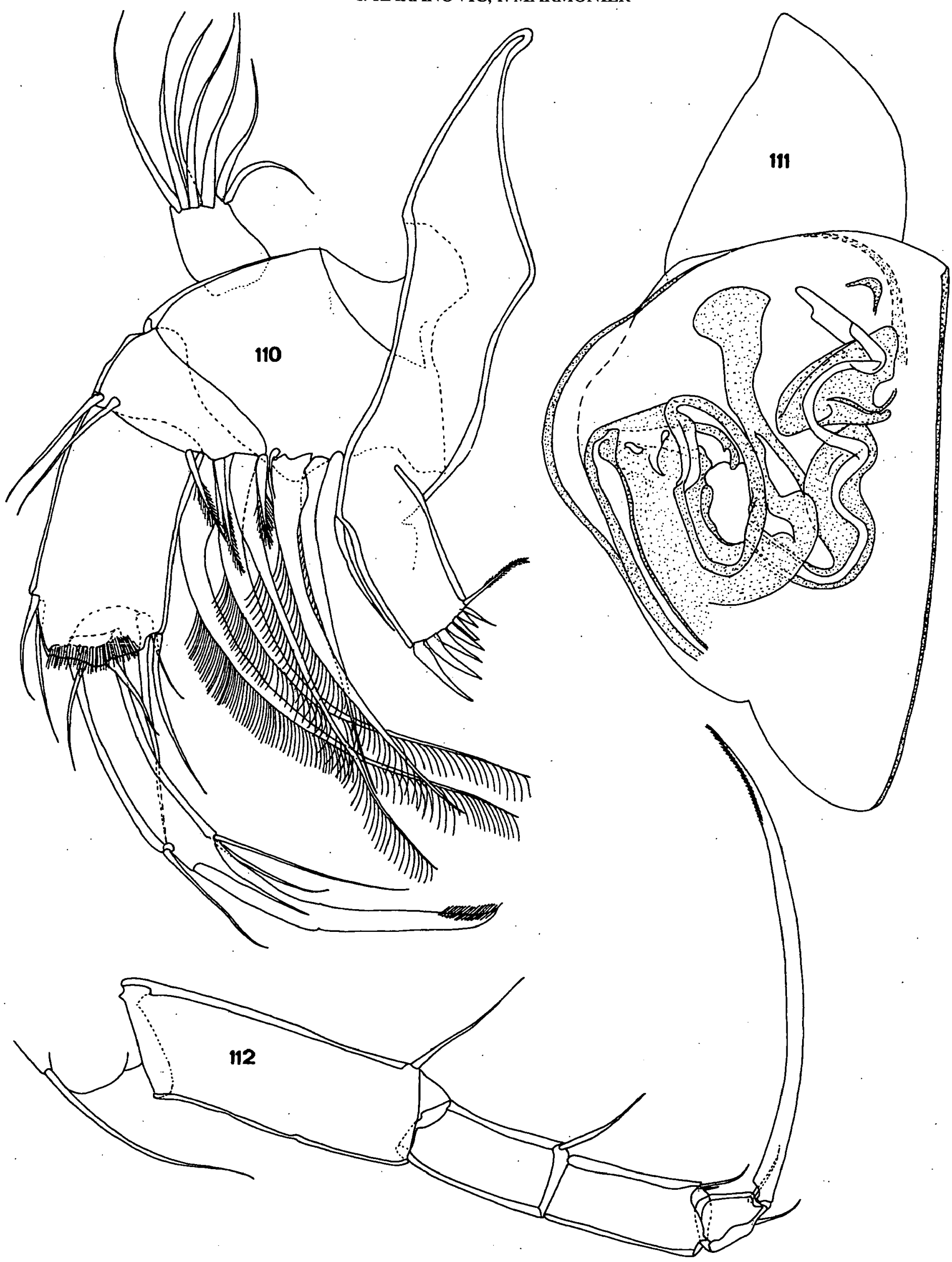

Figs. 110-112. Candonopsis westaustraliensis $\mathrm{n}$. sp.; holotype (male, $\mathrm{L}=0.694 \mathrm{~mm}$ ): 110-Md; 111-hemipenis; $112-\mathrm{T} 2$. Scales = 0.1 mm. Figs. 110-112. Candonopsis westaustraliensis $\mathrm{n}$. sp.; holotype (mâle, $\mathrm{L}=0.694 \mathrm{~mm}$ ): 110-Md; 111-hémipénis; $112-\mathrm{T} 2$. Echelle =0.1 mm. 
(35)

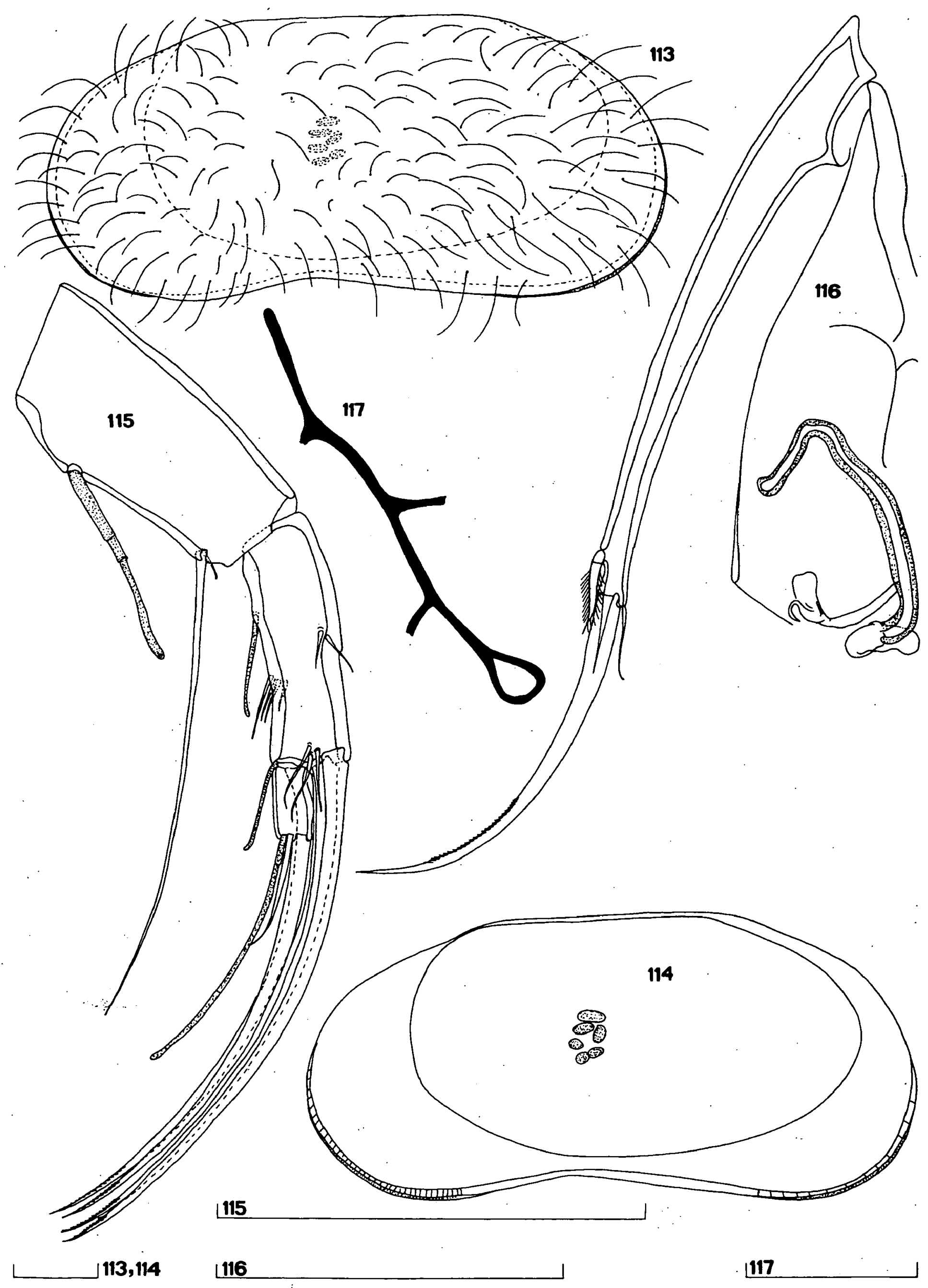

Figs. 113-117. Candonopsis westaustraliensis n. sp.; allotype (female, $\mathrm{L}=0.723 \mathrm{~mm}$ ): 113-LV, external view; 114-RV, internal view; 115-A2; 116-Fu with genital segment; 117-furcal attachment. Scales $=0.1 \mathrm{~mm}$.

Figs. 113-117. Candonopsis westaustraliensis n. sp.; allotype (femelle, $\mathrm{L}=0.723 \mathrm{~mm}$ ): 113-LV, vue externe; 114-RV, vue interne; 115-A2; 116Fu avec segment génital; 117- attache de la furca. Echelle $=0.1 \mathrm{~mm}$. 
postero-distally (reaching distal end of following segment), and one seta antero-distally (reaching distal end of terminal segment). Fifth segment also with short seta postero-distally (reaching middle of penultimate segment) and one long seta (exceeding distal end of terminal segment) antero-distally. Penultimate segment with totally five setae, alpha being very short and hardly visible. Terminal segment with two long, one short seta and aesthetasc (ya) which 3.25 times as long as terminal segment. $\mathrm{L}$ ratios of five endopodal segments $1.15: 1: 1: 1.5: 1.5$.

A2 (Fig. 107) 5-segmented, and with well developed male's bristles. Exopodite with two short and one long seta. Aesthetasc Y 3.1 time as long as first endopodal segment, y1 slightly exceeding distal end of third segment, y2 exceeds distal end of terminal segment, y3 4.1 times as long as terminal segment. Claw G2 well developed and 1.7 times as long as first endopodal segment, seta $\mathrm{z} 2$ transformed into claw which as long as claw G2. Claws $\mathrm{G} 1$ and $\mathrm{G} 3$ reduced, $\mathrm{G} 1$ being claw but just 2.7 times as long as terminal segment, while G3 being seta-like which 1.1 times as long as same segment. Seta z1 2.7, z3 1.1 times as long as terminal segment. $L$ ratios of four endopodal segments 4.4 : $2.1: 1.8: 1$.

Md (Fig. 110) with $3+2$ setae in bunch on second segment and two setae externally on same segment. Penultimate segment with two setae extero-distally and five setae distally. $\mathrm{L}: \mathrm{W}$ raio of terminal segment $5: 1$. Subterminal and terminal segment equally long.

Mxl palp (Fig.106) with four pappose setae distally on first segment and five appendages observed on terminal one.

T1 (Fig. 109) with one «a» seta, «b» and «d» setae present. Right prehensile palp much bigger (Fig. 109) than left one (Fig. 108) and with long subapical structure, while latter one with short such structure.

T2 (Fig. 112) 5-segmented. First segment with one seta (on Fig. 112 this segment rotated). First and second endopodal segments with one distal seta each, first one almost reaching distal end of following segment, latter one reaching middle of penultimate segment. Penultimate segment with two small setae. Terminal segment with two setae and claw which 1.25 times as long as three distal segments combined, and distally serrated.

T3 (Fig. 103) 5-segmented. Basal segment with all three setae present. Seta «e» exceeding middle of following segment, seta «f» exceeding distal end of penultimate segment., seta «g» exceeding distal end of terminal segment. $\mathrm{L}$ ratio of «h» setae $1: 1.5: 2$. All setae pappose.

Furcal ramus (Fig. 104) posteriorly without rows of spines. Posterior furcal claw reduced into strong, pappose and swollen seta. Anterior claw well developed, without spine but serrated. L ratios of anterior furcal margin, anterior claw and posterior seta-claw as follows $4.6: 3.8: 1$. Anterior seta six times shorter than anterior claw.

Hemipenis (Fig. 111), with triangular «a» lobe, «b» lobe flat, «h» rounded.

Description of female (Allotype): Carapace subreniform (Fig. 113). Dorsal margin not so inclined towards anterior end as in male. Both frontal and caudal margins equally wide. $\mathrm{L}$ of carapace equals $0.723 \mathrm{~mm}$. Greatest $\mathrm{H} 50 \%$ of $\mathrm{L}$. Other characteristics of carapace same as in male.

A2 (Fig. 115) with all «t» setae developed on penultimate segment. Aesthetasc Y 0.65 times as long as first endopodal segment, $y 1$ exceeds middle of second endopodal segment, $\mathrm{y} 3$ exceeds distal end of terminal segment, y3 four times as long as terminal segment. All G claws well developed and 1.75 times as long as first endopodal segment, while GM as long as same segment. Claw Gm 1.85 times as long as terminal segment. All «Z» setae visible and as long as terminal segment.

Fu (Fig. 116) with reduced posterior claw into seta, which also pappose and swollen. $\mathrm{L}$ ratios of anterior furcal margin, anterior claw and posterior claw-seta $5.3: 4.2: 1$. Genital segment rounded and without any extensions. Furcal attachment shown on Fig. 117.

All other appendages same as in male.

\section{Discussion}

The most unusual Australian species, described in the present paper, is Candonopsis westaustraliensis n. sp. It is characterized with the posterior furcal claw which is reduced into short, swollen and pappose seta. The appearance of terminal segment of Md palp, where $\mathrm{L}: \mathrm{W}$ ratio is $5: 1$, typical Candonopsis appearance of hemipenis, and prehensile palps, clearly relate this Australian species to the genus Candonopsis. Another two Australian species that stand apart from the rest of Candonopsis are Candonopsis williami $\mathrm{n}$. sp. and Candonopsis kimberleyi $\mathrm{n}$. sp. The first one lack basal seta on protopodite $\mathrm{T} 1$, has only two setae on basal segment T3, and lack medial seta on the second endopodal segment T3. This last feature it shares with Candonop- 
sis kimberleyi which, additionally, has rounded «a» lobe on hemipenis, trapezoidal valve forme, and it lacks one distal seta on penultimate segment of Md-palp. Despite of all these characteristics, both species clearly belong to the genus Candonopsis for the same reasons as $C$. westaustraliensis does. Reduction of the posterior furcal claw is noticed also in $C$. thienemani Schäfer, 1945, described from subterranean waters of Greece (Schäfer 1945), but in this species the reduction is of a completely different nature, as posterior claw is thin, more seta-like, and reaches more than $1 / 2$ L of anterior one. According to Schäfer (1945) this species also lack one seta on the basipodite T3, like in C. williami $\mathrm{n}$. sp.. Another feature in common to three new Australian species, mentioned above, is the presence of just one «a» seta on the protopodite T1. This is an additional characteristic which separates them from Candonopsis murchisoni n. sp., C. dani n. sp., and C. tenuis (Brady, 1886). This feature is not known in many Candonopsis species, so we cannot discuss its relevance. Both Candonopsis murchisoni and C. dani are more «typical» Candonopsis species, as they have developed all setae and claws, like in the type species of the genus. They can be easily distinguished from other representatives of the genus on the basis of carapace appearance, details of the hemipenis and strongly asymmetrical valves, where RV overlaps LV dorsally with clear flange. Because both species are very similar, their most noticeable distinguishing features will be explained in more details:

1. C. murchisoni has finely ornamented carapace surface, C. dani has not.

2. Caudal margin is almost straight in $C$. dani, while it is clearly narrower and more inclined in C. murchisoni.

3. Fourth segment of A1 bears anteriorly one long and one short seta in C. murchisoni, while there is just one short seta in $C$. dani.

4. L ratio of anterior and posterior furcal claws in $C$. murchisoni is $1.1: 1$ (male), $1.2: 1$ (female), while in C. dani it is $1.4: 1$ (male) and $1.5: 1$ (female).

5. Lobe «b» on hemipenis has a squarish extension in C. murchisoni while it is rounded in C. dani.

Gupta (1988) described C. urmilae from the subterranean waters of Bihar (India), species with very short furcal ramus and strongly asymmetrical valves, but in contrast to $C$. murchisoni and $C$. dani, LV overlaps RV dorsally. This species also has a pitted carapace surface like $C$. westaustraliensis. Generally, the ornamentation of carapace is very rare in the genus, as most of the world species have smooth valves, and a reniform or subreniform valve shape is a common feature for the most of species. There are just a few species with different appearance, like Candonopsis trichota Schäfer, 1945, C. thienemani Schäfer, 1945 and C. mareza Karanovic \& Petkovski, 1999 that have a triangular valve form, and C. putealis Klie, 1932 which has a trapezoidal valve form. The last species, described from subterranean waters of Java (Klie 1932), has carapace of very similar appearance to $C$. kimberleyi. However, the new species has ornamented valves, rounded distal end of hemipenis, while $C$. putealis has smooth carapace and pointed distal end of hemipenis.

There is no doubt that all newly described species from Australia are clearly distinguishable from the rest of world Candonopsis, as can also be concluded from the key given in this paper. Unfortunately, most of the other Candonopsis species were described a long time ago, without any new findings and redescriptions. For this reason most of the details regarding their morphology remain poorly known and difficult to compare here. In the key to world species we did not include two species : Candonopsis brasiliensis Sars, 1901 and Candonopsis transgrediens $\mathrm{Brehm}, 1923$. They are considered incertae sedis, owing to their incomplete descriptions. The former was described from Brasil, but Sars (1901) gave insufficient details about the morphology of its soft parts. He only drew the carapace and stated, for the rest of its morphology: «This form undoubtly belongs to the genus Candonopsis as defined by Vavra. It is nearly allied to the typical C. Kingsleii Brady and the Australian species C. tenuis Brady, though differing conspicuously from both in the shape of the shell». This is insufficient to give $C$. brasiliensis the right systematic position within the genus. Candonopsis transgrediens is described from China, but Brehm (1923) did not provide details of its carapace. Also, all the other morphological characteristics, like «special» appearance of furcal claws when seeing from lateral side (see Brehm 1923 : Fig. 10-1), are not sufficient enough, even more because the furca has a completely normal appearance when seeing in another aspect (see Brehm 1923 : Fig. 10-3). Appearance of the furcal claws that misled Brehm were only caused with the position of the furca when covered with coverslip. Brehm (1923) compared his species only with C. tenuis and C. solitaria, and distinguished it from them on the basis of the appearance of furcal claws, i. e. C. transgrediens has a spine only on the posterior claw, while the other two species have spines on both furcal claws. Today, this does not provide adequate information to place $C$. transgrediens in the right syste- 
matic position. Firstly, there are other species, like C. nama Daday, 1913, which has the furca of the same appearance, secondly, because there are no details regarding its carapace shape. Modern knowledge of the genus Candonopsis, including the present paper, questions how important is the presence of spines on one or both furcal claws, and how constant within the species this feature is, to be a distinguishing character?

Klie (1932) divided the genus Candonopsis into three groups of species according to the presence of spines on the furcal claws. The first group contained species with spines on both claws. In Klie's time they were : Candonopsis solitaria Vavra, 1895, C. tenuis (Brady, 1886) and C. navicula Daday, 1910. Klie (1944) included C. africana in this first group of species. Subsequently, Martens (1984) reported that $C$. africana, collected from the type locality (Lake Kivu), showed variation in the appearance of the furcal claw : a distinct spine being present on both, or else only on the anterior claw.

Klie's (1932) second group consists of species that do not possess spines on either of the furcal claws. He included two European species : Candonopsis kingsleii (Brady \& Robertson, 1870) and C. scourfieldi Brady, 1910, and three South American species: C. falclandica Vavra, 1898, C. anisitsi Daday, 1905 and $C$. columbiensis (Méhes, 1913). Here, we would like to propose the exclusion of these South American species from the genus Candonopsis for the following reasons : all three species have completely different appearance of hemipenis than all other Candonopsis; they have clearly more symmetrical prehensile palps; and $L: W$ ratio of the terminal segment of Md palp is less than $3: 1$ (more likely $2: 1$, or even $1: 1$ ). According to the drawings of the hemipenis provided by Vavra (1898 : Fig. 2/7), Daday (1905 : Plate 16, Fig. 23) and Méhes (1913: Fig. 15/i), it can not be ascertained whether there are actually two «a» lobes, or whether both lobe «a» and «b» are of the same height, an attribute not seen in other Candonopsis species (see revised diagnosis in the present paper). Daday's drawings are, however, the most similar to the appearance of the hemipenis apparently having two «a» lobes. Méhes (1913 : Fig. 15/e, f) and Daday (1905 : Plate 16, Fig. $21,22)$ illustrated very symmetrical prehensile palps, having two subapical sclerified structures. All other Candonopsis have right prehensile palp considerably bigger than left one, and it seems that all have both palps with exclusively one subapical sclerified structure. On Vavra's drawings (1898 : Fig. $2 / 5$ and $2 / 6$ ) the right palp is indeed more robust than left one. However, we consider that he may have misinterpreted the subapical structure on the right prehensile palp, as there are clearly two, and overlooked the smaller one on the left palp. Subapical structures of similar appearance on the prehensile palps, such as Vavra (1898) noticed, are also found in the representatives of the genus Caribecandona Broodbakker, 1983. The asymmetry of prehensile palps found by Vavra (1898) may be consistent with Broodbakker's (1983) observation regarding prehensile palps in the genus Caribecandona : «Because of the torsion, the proximal part of the endopodite seems to be wide on one side and narrow at the other». Finally, all three species seems to have a short terminal segment of Md palp, what is clearly stated by Méhes (1913), while Vavra (1898) just said that it is short, and Daday (1910) did not provide this detail. However, when redescribing $C$. anisitsi, Klie (1930) stated that this segment is more than two times longer than wide, but did not give any further dimension. Vavra's (1898) description of this segment made us suspicious as he gave the diagnosis of the genus where long terminal segment of mandibular palp is considered one of the generic features. The appearance of this segment

in C. columbiensis is additionally strange, as on Méhes's (1913 : Fig. 15/d) drawings this segment has, instead of one central and fused claw, two equal ones not fused with segment, as well as two smaller and more setalike.

When Broodbakker (1983) described the genus $\mathrm{Ca}$ ribecandona, he also divided it into two subgenera : Caribecandona and Cubacandona. The first one includes three species, while only the species Caribecandona (Cubacandona) cubensis (Danielopol, 1978), previously described from Cuba (Danielopol 1978, 1980), belongs to the second subgenus. The characteristics of the nominate subgenus are : six segmented A1, male's bristles present, reduced posterior furcal claw, 3 setae on the basipoditae T3, one «a» lobe rounded, other acuminate. C. (Cubacandona) cubensis is characterized with 7-segmented A1, absent male's bristles, basipodite of T3 with two setae, both furcal claws developed, one «a» lobe quadriform, other rounded. At least the number of segments on A1 and a constant reduction of furcal claws are generic characteristics, so we would like to propose elevation of two subgenera onto the generic level. However, those two genera remain closely related. According to the features of three above mentioned South American Candonopsis, they are more closely related to the genera Cubecandona Broodbakker, 1983 and Caribecandona Broodbakker, 1983 than to the genus Candonopsis, and because of that are not included into the key of the 
genus Candonopsis. The number of the segments on $\mathrm{A} 1$, the general appearance of the hemipenis and furcal claws may lead to the conclusion that they belong to the, previously monospecific genus, Cubacandona, but the firm conclusion needs to await their redescription.

The third and last group proposed by Klie (1932) encompasses species with a prominent spine on just the posterior furcal claw. Until 1932 the following species fitted into this group : C. nama Daday, 1913, C. transgrediens Brehm, 1923, C. sumatrana Klie, 1932, and C. putealis Klie, 1932. Afterwards, the following species were reported with the same furcal appearance : $C$. bujukensis Löffler, 1968; C. fessleri fessleri Löffler, 1968, and C. f. daburai all from Kenya (Löffler 1968), and C. calva described from a fish gut caught on Solomon Islands (Harding 1962). In our opinion, C. fessle$r i$ can not be distinguished from $C$. nama, of which it should be considered as a junior synonym and therefore not included in the key. It has the same appearance of both carapace and soft parts; differences in prehensile palps, used by Loffler to distinguish his species from C. nama, are not at all prominent. Victor \& Fernando (1979) reported species $C$. putealis from southwest India. According to their drawings (see Victor \& Fernando 1979 : Fig. 364-365) and description of furca (citation: «both the claws armed with distinct group of spines»), it is not clear if both claws lack two prominent spines or they both have one. However, the shape of the carapace and undivided second endopodal segment T3, more clearly relate this species to $C$. $n a$ ma Daday, 1913 than to $C$. putealis Klie, 1932. In the description of $C$. calva, Harding (1962) stated : «the proximal claw is a little shorter than the distal one and has a strong spine in the middle, while the distal claw has only a very weak spine in this position.» According to all this, it is hard to ascertain the boundary between prominent and weak spine on furcal claws. Australian Candonopsis are an additional confusing elements. In $C$. murchisoni both furcal claws might have spine (Fig. 20), spine is visible just on the posterior claw (Fig. 21), or it is prominent on the posterior claw, while weak on anterior one (Fig. 35). The situation in C. dani is quite similar: spine can be developed on both claws (Fig. 47), visible just on anterior claw (Fig. 44 ), or in female developed just on the posterior claw (Fig. 56). Males of C. kimberleyi have both claws with prominent spines (Fig. 96), while in females the situation can be the same (Fig. 98), or spine is present on just posterior claw (Fig. 99). C. tenius has both claws in both sexes with a spine (Fig. 10,14), C. williami has claws without spines (Fig. 70, 71, 80), as well as $C$. westaustraliensis (Fig. 104, 116). It seems that in the genus Candonopsis both furcal claws may lack spine, which is most probably stable characteristic (in C. kingsleii, $C$. scourfieldi, $C$. boui and $C$. mareza). On the other hand, there is a number of intermediate stages between the situation when both claws have prominent spine, and when the spine is prominent on just one of the claws. In spite of this, on one stage of our key, we had to introduce presence of one prominent spine on just posterior claw, or just anterior one. Also, we had to include $\mathrm{L}$ as a distinguishing feature although it is very weak argument for a species. We did this, because there is a group of species with very similar carapace shape, and other details of morphology and the above mentioned features were the only arguments for some of the authors to describe those species. However, without enough evidence and without details of their morphology, it was impossible to synonymize them, although differences between some of them are weak. This group include the following species (order from the key) : C. solitaria Vavra, 1895; C. tenuis (Brady, 1886), C. africana Klie, 1944, C. hummelincki Broodbakker, 1983, C. nama Daday, 1913; C. bujukensis Löffler, 1968, C. sumatrana Klie, 1932; and C. calva Harding, 1962. Broddbakker (1983) provided details of the chaetotaxy of female's antenna, where all t-setae are present. The same has been done by Danielopol (1980) for the species $C$. africana which also has all tsetae. This feature distinguishes them very nicely from C. tenuis as females have only two t-setae (Fig. 16), but not from each other. Actually, their soft parts are very similar, as well as carapace shape, and only differences is in their carapace $\mathrm{L}$ ( $C$. africana more than $0.85 \mathrm{~mm}$; $C$. hummelincki less than $0.7 \mathrm{~mm}$ ) and $\mathrm{L}$ : W ratio of terminal segment of Md-palp (C. africana $6: 1$; C. hummelincki $7: 1$ ), which is actually not very noticeable. Only slight difference in carapace shape, difference in the presence of spines on one or both furcal claws distinguish $C$. tenuis from $C$. sumatrana, $C$. calva, C. nama, and C. bujukensis, as well them from each other. Maybe redescription of all four species can give additional morphological details for their easier distinguishing, or can prove that they are actually one species with wider tropical and subtropical distribution. As this has not yet been provided, we consider them all valid species, and they are included in the key. 


\section{1. Key to world species of the genus Candonopsis}

1. Posterior furcal claw reduced

Both furcal claws developed, and well sclerotized

2. Posterior furcal claw reduced into thin, long seta (more than $1 / 2 \mathrm{~L}$ of anterior claw)

- Posterior furcal claw reduced into swallen, pappose and short seta (less than 1/3 L of anterior

\section{C. thienemani Schäffer, 1945}

C. westaustraliensis $\mathrm{n} . \mathrm{sp}$.

3. Second endopodal segment of the cleaning leg medially without seta

- Same segment medially with seta

4. Basal segment on $\mathrm{T} 2$ without seta C. williami in. sp.

- Basal segment on T2 with seta C. kimberleyi n. sp.

5. Anterior furcal claw shorter than ramus

- Anterior furcal claw clearly longer than ramus

C. urmilae Gupta, 1988

6. Valves strongly asymmetrical: dorsally $\mathrm{RV}$ overlaps $\mathrm{LV}$ with flange

- RV equally high, or lower than LV

7. Furcal claws of subequal $L$, or anterior claw slightly longer than posterior one (at the most 1.2 times)

- Anterior furcal claw always markedly longer than posterior one (at least 1.4 times)

\section{C. murchisoni n. sp.} C. dani n.sp.

8. $\mathrm{L}: \mathrm{W}$ ratio of terminal segment of Md palp $7: 1$ or less

$\mathrm{L}: \mathrm{W}$ ratio of terminal segment of Md palp $9: 1$

C. anteroarcuata Rome, 1962

9. Setae on first and second endopodal segment of $\mathrm{T} 3$ extremely short

- Same setae at least reaching $1 / 3$ of following segments

10. Exopodite T1 with two branchial fialments

Exopodite $\mathrm{T} 1$ with three branchial filaments

11. Neither of furcal claws carries spine

- At least one of furcal claws with distinct spine

12. Carapace subtriangular

- Carapace reniform to subreniform, elongated

13. Anterior and posterior ends of carapace covered with long, stiff, spine-like hairs, posterior and anterior furcal claws equally long

- Anterior and posterior ends of carapace with fine hairs, posterior furcal claw shorter

C. trichota Schäffer, 1945

C. dorsorecta Rome 1962

C. depressa Rome, 1962

C. mareza Karanovic \& Petkovski, 1999

14. $\mathrm{L}: \mathrm{W}$ ratio of terminal segment of Md-palp less than $4: 1$

- $\mathrm{L}:$ W ratio of terminal segment of Md palp $5: 1$ up to $6: 1$

15. Distal lobe «a» of hemipenis more triangular and pointed

- Same lobe more squarish and oblong

C. kingsleii (Brady \& Robertson, 1870)

C. boui Danielopol, 1978

16. Anterior furcal seta missing

C. scourfieldi Brady, 1910

Anterior furcal seta present

17. Cadal and frontal margins equally wide, or caudal one slightly narrower than anterior one, dorsal margin slightly concave in the middle, carapace trapezoidal

- Caudal margin clearly wider than anterior one, dorsal margin straight, carapace reniform ...

C. navicula Daday, 1910

18. L of carapace between $0.55 \mathrm{~mm}$ and $0.65 \mathrm{~mm}$

C. solitaria Vavra, 1895

- L. of carapace always more than $0.75 \mathrm{~mm}$

19. Anterior furcal claw with strong spine, while on posterior claw spine sometimes weaker

- Posterior claws always with strong spine, while spine on anterior claw very weak

20. All t-setae in female on A2 developed

- Just two t-setae present

21. $\mathrm{L}$ of carapace more than $0.85 \mathrm{~mm}, \mathrm{~L}: \mathrm{W}$ ratio of terminal segment of Md palp $6: 1$

- $\mathrm{L}$ of carapace less than $0.7 \mathrm{~mm}$ and $\mathrm{L}: \mathrm{W}$ ratio of terminal segment of Md-palp $7: 1$

22. In lateral view dorsal margin equally rounded, with greatest $H$ around middle

- In lateral view greatest $\mathrm{H}$ on the last third, from which point margin rounded towards posterior, and inclined towards anterior end

23. Seta $h 21.5$ times longer than $h 1$

- Seta $\mathrm{h} 2$ more than 2.5 times longer than h1

24. In lateral view dorsal margin sinusoid towards frontal margin

- In lateral view dorsal margin evenly rounded
C. nama Daday, 1913

C. bujukensis Löffler, 1968

C. sumatrana Klie, 1932

C. calva Harding, 1962 


\section{Acknowledgment}

The authors would like to thank Dr William F. Humphreys (Western Australian Museum, Perth) for reading the first version of the manuscript and providing important improvements. We are also thankful to Dr Henri Oertli (Bizanos, France) and Dr Claude Meisch (Museum of Natural History, Luxembourg) for supplying us with some very old references.

The senior author would like also to acknowledge the support of the australian biological resources study (ABRS) grant for the year 2002-2003.

\section{References}

Brady G. S. 1886. — Notes on freshwater entomostraca from South Australia. Proc. zool., Soc. Lond., 1886 (1) : 82-93.

Brady G. S. 1902. - On new or imperfectly - known ostracods, chiefly from a collection in the Zoological Museum, Copenhagen. Trans. zool. Soc. Lond., 16 (4) : 179-199.

Brady G. S. 1910. - A revision of the British species of ostracod Crustacea belonging to the subfamilies Candoninae and Herpetocyprinae. Proc. zool. Soc. Lond., 1910 (1) : 194-220.

Brady G. S. \& Robertson D. 1870. - The ostracoda and foraminifera of tidal rivers. Ann. Mag. nat. Hist., 4 (6): 1-33.

Brehm V. 1923. - Bericht uber die von Dr H. Weigoldd in China gesammelten Kopepoden und Ostrakoden. Int. Rev. ges. Hydrobiol. Hydrogr., 11 (3/4) : 329-345.

Broodbakker N. W. 1983. - The subfamily Candoninae (Crustacea, Ostracod) in the West Indies. Bijdr. Dierk., 53 (2) : 287-326.

Broodbakker N. W. \& Danielopol D. L. 1982. - The chaetotaxy of Cypridacea (Crustacea, Ostracoda) limbs : proposal for a descriptive model. Bijdr. Dierk., 52 (2) : 103-120.

Daday J. 1900. - A Magyarorszagi Kagylosrakok Maganrajza (Ostracoda, Hungarie). Kiadja Maghiar Tud. Akad., Budapest : 1320.

Daday J. 1905. — Untersuchungen über die Süsswasser-Mikrofauna Paraguays. Zoologica, 44 : 1-374.

Daday J. 1910. - Die Süsswasser-Mikrofauna Deutsch-Ost-Afrikas. Zoologica, $59: 1-314$.

Daday J. 1913. - Cladoceren und Ostracoden aus Sud- und Sudwestafrika. Denkschr. Med.-naturw. Ges. Jena, 70 : 92-102.

Danielopol D. L. 1969. - Recherches sur la morphologie de l'organe copulateur mâle chez quelques ostracodes du genre Candona Baird (fam. Cyprididae Baird). In: J. Neale W. (Ed.), The taxonomy, morphology and ecology of recent Ostracoda: Oliver \& Boyd Ltd., Edinbourgh : 136-153.

Danielopol D. L. 1978. - Über Herkunft und Morphologie der Süsswasser-hypogäischen Candoninae (Crustacea, Ostracoda). Sitz. Österr. Akad. Wiss., Mathem.-Naturwiss. Kl., Abt. 1, 187 (1/5): 1-162.

Danielopol D. L. 1980. — Deux espèces hypogées du genre Candonopsis (Ostracoda, Candoninae) du Sud de la France et de Cuba. Vie Milieu, 30 (3-4) : 315-323.

Gupta L. P. 1988. - Candonopsis urmilae a new species of subterranean Crustacea (Ostracoda : Candonidae) from India. Rec. zool. Surv. India, 85 (3) : 419-427.

Harding J. P. 1962. - Mungava munda and four other new species of Ostracod Crustaceans from fish stomachs. Nat. Hist. Rennel Island, British Solomon Islands, 4 : 51-62.

Humphreys W.F. 1999. - Relict stygofaunas living in sea salt, karst and calcrete habitats in arid northwestern Australia contain many ancient lineages. In: Ponder W. \& Lunney D. (Eds) The Other $99 \%$. The Conservation and Biodiversity of Invertebrates : 219227. Trans. r. zool. Soc. N.S.W., Mosman 2088.
Humphreys W.F. 2001. D. - Groundwater calcrete aquifers in the Australian arid zone : the context to an unfolding plethora of stygal biodiversity. In: Humphreys W. F. \& Harvey M.S. (Eds). Subterranean Biology in Australia 2000, Rec. West. Aus. Mus. Suppl. 64: 63-83.

Karanovic I. \& Marmonier P. (in press). - Three new genera and nine new species of the subfamily Candoninae (Crustacea, Ostracoda, Podocopida) from the Pilbara Region (Western Australia). Beaufortia.

Karanovic I. \& Petkovski T. 1999. - Two new species of the subfamily Candoninae (Ostracoda) from Montenegro (SE Europe). Crustaceana, 72 (6) : 603-616.

Kempf E. K. 1980. - Index and Bibliography of non-marine Ostracoda 1, Index A. Geol. Inst. Univ. Koeln Sonderver., 35 : 1-188.

Kempf E. K. 1997. - Index and Bibliography of non-marine Ostracoda 1, Index A, Suppl. 1. Geolog. Inst. Univ. Koeln Sonderver., $109: 1-142$.

Klie W. 1930. - Ostracoden aus dem paraguayischen Teile des Gran-Chaco. Arch. Hydrobiol., 22 : 221-258.

Klie W. 1932. - Die Ostracoden der Deutschen Limnologischen Sunda-Expedition. Arch. Hydrobiol., Suppl. 9 : Tropische Binnengewässer, $3:$ 447-502.

Klie W. 1935. - Ostracoda aus dem tropischen Westafrika. Arch. Hydrobiol., 27 : 35-68.

Klie W. 1936. - Ostracoden aus Kamerun. Rev. Zool. Botan. Afr., 27 (2) : 287-309.

Klie W. 1944. - Ostracoda. Exploration du Parc National Albert, Mission H. Damas. Inst. Parcs Nat. Congo Belge. 12 : 1-62.

L`ffler H. 1968. - Die Crustaceenfauna der Binnengewässer Ostafrikanischer Hochberge. Hochgebirgsforschung., 1 : 107-170.

Löffler H. \& Danielopol D. L. 1978. - Ostracoda (Cypridae). In: Illies J. (Ed.). Limnofauna Europaea : Gustav Fischer Verlag, Amsterdam, 196-208.

Martens K. 1984. - On the freshwater ostracods (Crustacea, Ostracoda) of the Sudan, with special reference to the Red Sea Hills, including a description of a new species. Hydrobiologia, 110 : 137161.

Martens K. 1987. - Homology and functional morphology of the sexual dimorphism in the antenna of Sclerocypris Sars, 1924 (Crustacea, Ostracoda, Megalocypridinae). Bijdr. Dierk., 57 (2) : 183-190.

Martens K. 1998. - General morphology of non-marine Ostracods. In: Martens, K. (Ed.). Sex and Partehnogenesis: evolutionary ecology of reproductive modes in non-marine ostracods : Backhuys Publishers, Leiden, The Netherlands, 57-75.

Méhes G. 1913. - Süsswasser-Ostracoden aus Columbien und Argentinien. Mem. Soc. neuch. Sci. nat., 5 : 639-663.

Meisch C. 1996. - Contribution to the taxonomy of Pseudocando$n a$ and four related genera, with the description of Schellencandona nov. gen., a list of the Candoninae genera, and a key to the European genera of the subfamily (Crustacea, Ostracoda). Bull. Soc. Nat. luxemb., $97:$ 211-237.

Müller G. W. 1912. — Ostracoda. Das Tierreich, 31 : 1-434.

Müller O. F. 1785. - Entomostraca seu Insecta testacea, quae in aquis Danie et Norvegie, reperit, descripsit. Lipsiae et Havnie : 1135.

Nuchterlein H. 1969. - Süsswasserostracoden aus Franken. Ein beitrag zur Systematik und Ökologie der Ostracoden. Int. Rev. ges. Hydrobiol., 54 (1) : 223-287.

Petkovski T. K. \& Meisch C. 1995. - Interesting freshwater Ostracoda (Crustacea) from Macedonia. Bull. Soc. Nat. luxemb., 96 : 167183.

Rome R. 1962. - Exploration Hydrobiologique du Lac Tanganika (1946-1947). 3. Ostracodes. Res. sci. Expl. hydrobiol. Lac Tanganyika, 3 (8) : 1-305. 
Sars G. O. 1896. - On fresh-water entomostraca from the neighbourhood of Sydney, partly raised from dried mud. Arch. Math. Naturv., 18 (3) : 1-81.

Sars G. O. 1901. - Contribution to the knowledge of the freshwater entomostraca of South America. Arch. Math. Naturv., $24(1): 1-52$.

Schäfer H. W. 1945. - Grundwasser-Ostracoden aus Griechenland. Arch. Hydrobiol., 40 (4) : 847-866.

Sywula T. 1967. - Notes on Ostracoda. II. On some Bulgarian species. Bull. Soc. Amis Sci. lett. Poznan, Ser. D, 8 : 11-42.

Vavra W. 1891. - Monographie der Ostracoden Bohmens. Arch. Naturwiss. Landesdurch. Bohmen, 8 (3) : 1-116.
Vavra V. 1895. - Die von Dr F. Stuhlmann gesammelten. Süsswasser-Ostracoden Zanzibar's. Jahrb. Hamb. Wiss. Anst., 12 : 1-23.

Vavra V. 1898. - Süsswasser-Ostracoden. Hamb. Magalh. Sammel. : 1-25.

Victor R. \& Fernando C. H. 1978. - Systematics and ecological notes on Ostracoda from container habitats of some South Pacific Islands. Can. J. Zool., 56 (3) : 414-422.

Victor R. \& Fernando C. H. 1979. - The freshwater ostracods (Crustacea, Ostracoda) of India. Rec. zool. Surv. India, 74 (2) : 147-242. 